\title{
THE MEDICINAL FLORA OF NATIVE NORTH AMERICA: AN ANALYSIS
}

\author{
DANIEL E. MOERMAN
}

Department of Behavioral Sciences, University of Michigan-Dearborm, Dearborm, MI (U.S.A.)

(Accepted August 4, 1990)

\section{Summary}

This paper describes an analysis of the plants of North America which have been used medicinally by Native North Americans. A method using regression residuals is developed for analyzing large quantities of data, divided into subgroups of varying sorts and sizes. The analysis shows that the medicinal species utilized by Native North Americans are distributed in a highly non-random fashion across subclasses and families as well as across groups defined in terms of growth habit and life pattern. This distribution makes sense in terms of both the defensive chemistry and the "complexity" of plants.

\section{Introduction: Analyzing ethnobotanical data}

According to an authoritative source (Shetler and Skog, 1978) there are, in North America north of the Rio Grande, 16,270 species of vascular plants. According to another recent source, Medicinal Plants of Native America (Moerman, 1986), 2147 of them were used medicinally by 123 Native North American (hereafter termed "Native American") societies in 17,624 different ways. What is the relation of the smaller set to the larger? Those familiar with medical ethnobotany will note that this is an unusual question and an unusual approach. The more typical approach involves dealing with different species seriatim, assessing the ethnological and physiological character of particular taxa. The attempt is made here to do something different, namely, to analyze the dimensions of the totality of Native American medicinal plants; it is to analyze the medicinal flora of the continent as one thing, not 2000 or 17,000 things.

This study will consider a subset of the somewhat larger number of items in Medicinal Plants of Native America. A number of those species have been eliminated from consideration here for one of several reasons, including incomplete identification, lack of complete distributional data and the like. A 
small number of complex agricultural species (such as cabbage), usually introduced, have also been eliminated, leaving a total of 2095 species used in 15,843 different ways.

\section{Methodology}

There are two assumptions underlying most of the analyses undertaken here.

The first assumption is that the data are not a sample of the uses of medicinal plants by Native Americans, but a census. This is a very strong assumption, yet one which seems reasonable. While it might be possible with intensive ethnographic fieldwork to gain new items (say, in central Canada or in Florida) it is unlikely that such work would markedly increase the number of medicinal species recognized. The database referred to is in its second edition, much larger than the first (Moerman, 1977). The number of items in the current edition is 3.6 times that of the first edition $(17,634 \mathrm{vs}$. 4869). Yet, the number of species described increased by only a factor of 1.7 (2147 vs. 1288) and the number of genera increased by only a factor of 1.4 (760 vs. 561 ). It seems very unlikely that even sustained fieldwork would markedly increase the number of medicinal taxa already known and compiled.

This has several consequences. First, statistical tests of significance are irrelevant since they are designed by and large to give one confidence that the sample drawn is a representative one, that if another sample were drawn it would have characteristics similar to the first. In this case, no other "sample" can be drawn; to repeat the ethnographic work would produce the same assortment of data. Second, there is no need to make "predictions" about the material, about how Native Americans might use medicinal plants, since that is already known. All of these notions make this sort of analysis seem a bit odd sometimes; the quid pro quo of this oddness is that analysis of a census allows much stronger inferences about human behavior than does the much more curtailed analysis of a sample (based on a poll of, say, 20 or 400 persons). Handling huge numbers of datapoints $(15,000$ or 17,000$)$ does introduce serious technical problems, however. Analyses like the ones presented here are inconceivable without quite sophisticated computers and software.

The second assumption is an even stronger and more circumstantial one, based on the assertion of a negative proposition, that the census of data reported here represents not only all the medicinal plants known to Native Americans, but also all the plants in the region with any potential medicinal use. That is, the data represent a census not only of ethnological data but also of botanical data. The primary reason for making this assertion is that no one ever finds a "new" medicinal plant, one lacking a history of use among Native Americans. It is true that, occasionally, new uses are found for previously known medicinal species. Two cases may be cited. 
First, etoposide has recently been approved by the FDA as a treatment for small cell lung cancer and for refractory testicular tumors (Berkow, 1987). Etoposide is a semisynthetic derivative of the roots of the may apple, Podophyllum peltatum L. (Berberidaceae). While may apple was extensively used by Native Americans as a cathartic, a laxative, a tonic and the like, there is no significant reason to believe that they used it to treat cancer.* Indeed, Native Americans seem to have had very few treatments of any kind for cancer, probably because they only rarely suffered from the disease (e.g., for the Navajo see Csordas, 1989).

Second is the case of Erythrina herbacea L. (Fabaceae). African American informants on St. Helena Island in South Carolina reported using what they called "big root" as a treatment for "high blood" and fever (Moerman, 1974). The present author initially reported this as an independent discovery of those informants. The genus Erythrina is widespread in tropical America and has received a good deal of study; its biological action is described as "curare-mimetic" depressing the action of smooth muscle tissue, thereby (among other things) causing a fall in blood pressure (Hargreaves et al., 1974). Subsequently, however, Ayensu (1978) reported that Erythrina mildbraedii Harms, the Senegal coral tree, very similar in appearance to the plant used by those informants in South Carolina, was widely used medicinally throughout West Africa. This is what the African American literature calls an African "survival": the African-Americans probably had not discovered a "new" medicinal plant but had recognized an old one in a new setting. Subsequent research showed that Alabama and Creek Indian women had used Erythrina herbacea for "bowel pain" (Swanton, 1928) and that the Choctaw used a decoction of the leaves as a general tonic (Bushnell, 1909). Merrill (1977) argues that seeds of Erythrina flabelliformis Kearney are sometimes substituted for mescalbeans in the American southwest as a ceremonial adjunct to the process of inducing visions. Hence, these species probably had some antiquity as a medicine in both the south and southwest, and, as

\footnotetext{
*While it is occasionally stated that the Penobscot Indians of Maine used may apple to treat cancer (e.g., Hartwell 1982), the citations seem always traceable to the same source, Lucina Lombard's "Medicinal Plants of Our Maine Indians" (Lombard 1952). This interesting paper seems most likely to be based on the remembrances of Lombard's father, probably an eclectic physician trained in the 1890s. It is full of references to various plants used as nervines and pectorals and used to treat malaria, ague, scrofula and gravel, all terms meaningful in turn-of-thecentury American medicine, but rarely so in Native American medicine. Speck's earlier and much more authoritative work makes no mention of Penobscot cancer cures (Speck, 1917). Hartwell also states that podophyllin resin "was used. . . by urologists and popularly in Louisiana for many years for the treatment of venereal warts" (Hartwell 1982). His reference for this information is an article by Sullivan and King on the medical use of podophyllum: "For many years, according to Kittredge, the urologists in New Orleans have treated genital verrucae with topical applications of resin of podophyllum" (Sullivan and King, 1947). Their reference to Kittredge is a "Personal communication to the authors". Neither of these sources seems sufficient to conclude that podophyllum was a popular remedy or an Indian remedy for cancer.
} 
always seems to be the case, no one ever finds a "new" medicinal plant not already known to Native Americans, although sometimes new uses are found for known taxa. One crucial consequence of this assumption is that, insofar as it is true, the presence of a taxon in this category grants the plant a certain botanical character: it is a "medicinal" plant, different from others.

\section{A. Regression analysis}

How can one actually analyze 15,843 things at the same time? It is not a simple problem. The basic question raised is comparative: "How do medicinal species compare to available species?" Is there a structure underlying these thousands of choices? The null hypothesis states that there is not; that there is no real difference between available and chosen taxa, that the use of medicinal plants by Native Americans was random behavior.

Recognizing that botanists sort plant species into families, it could be asked "Which families have the largest number of medicinal species?" The top 3 are Asteraceae with 345, Rosaceae with 115 and Fabaceae with 108. But these are very large families: Asteraceae has 2231 species listed in the Flora North America checklist, hereafter termed "FNA" (Shetler and Skog, 1978), while Rosaceae has 577 and Fabaceae has 1225. This suggests that the proportion of species, not the number, should be considered. There are, however, 7 small families in North America with only one, two or three species, all of which are used medicinally (among them Datiscaceae with one species, Saururaceae with two and Calycanthaceae with three). Ordered this way, families which stood out in the first ordering are now lost in the crowd: Rosaceae is in the 70th position, Asteraceae is 89th and Fabaceae is 115th. While a simple count of medicinal species overemphasizes large families, percentages or indices overemphasize small ones.

There are other problems. Neither the Agavaceae nor the Zingiberaceae have any medicinal species in North America; the two would share the same ranking on each of these lists (by count and by percentage, both zero on each list). There are, however, 86 species in the former and only one in the latter; it seems somehow more significant that none of the 86 species of Agavaceae is used than that none of the one species of Zingiberaceae is.

An approach which addresses most of these problems, analysing residuals from regression, was first attempted with a much smaller set of data (Moerman, 1979). A least-squares regression analysis establishes an equation which states a relationship between two (or more) sets of data. In this case, a regression equation describes a relationship between the total number of species in each of the 232 families of plants (the independent variable) and the number of species used medicinally in each family (the dependent variable). The total number of species per family is derived from the FNA checklist (Shetler and Skog, 1978) and for convenience is labeled FNASPE; the number of species used medicinally is derived from Medicinal Plants of Native America (hereafter MPNA; Moerman, 1986) and is labeled MPSPE. 
Assuming that the relation is linear, such an equation will have the following form:

$$
y=A+B x
$$

where $y$ is a dependent variable, $x$ an independent variable, $B$ a coefficient and $A$ a constant.* In the current case, the equation is as follows:

$$
\text { MPSPE }=1.21+(0.1115 \times \text { FNASPE }) .
$$

According to this equation and under the null hypothesis, the number of medicinal species per family should be equal to the total number of species in that family multiplied by 0.1115 , plus 1.21 . Thus, the equation predicts that 250 of the 2231 species of Asteraceae would be used medicinally:

$$
\begin{aligned}
\text { MPSPE } & =1.21+(2231 \times 0.1115) \\
& =1.21+248.76 \\
& =249.97
\end{aligned}
$$

However, there are actually 345 medicinal Asteraceae. Subtracting the predicted value from the actual value gives us the residual value for this data point for the regression analysis; in this instance, the residual is 95 . A residual value can be calculated for each family. Families with positive residuals are ones used more often than the regression would predict while those with negative residuals are used less often than predicted; insofar as these differences are large, the null hypothesis is rejected, and choices were not made at random. Analysis and interpretation of the residuals allows us to determine what if anything underlay the choices made. Table 1 shows the actual data and the predicted and residual values for all the families mentioned so far; the complete data for all 232 families are shown in Appendix A.

It is sufficient at this point to note that, in this ordering of the data, the "ties" noted earlier (between Calycanthaceae, Saururaceae and Datiscaceae and between Agavaceae and Zingiberaceae) do not occur and the influence of large families has been substantially overcome (as shown by Fabaceae, last in the Table).

\section{B. Plant defenses and biologically active plant substances}

This approach will raise complex questions of why it is that plants pro-

\footnotetext{
"The coefficient represents the slope of the line while the constant represents the intercept, where the equation crosses the $y$ axis (when $x$ is 0 ). The coefficient and constant are determined using the traditional method of least-squares regression. See Snedecor and Cochran (1967) for a complete and classic demonstration of the mathematics involved in the calculations.
} 
TABLE 1

SELECTED RESULTS OF REGRESSION ANALYSIS

\begin{tabular}{lrccc}
\hline Family & FNASPE $^{a}$ & MPSPE $^{b}$ & Predicted & Residual \\
\hline Asteraceae & 2231 & 345 & 250 & 95 \\
Rosaceae & $\mathbf{5 7 7}$ & 115 & 66 & 49 \\
Calycanthaceae & 3 & 3 & 1.6 & 1.4 \\
Saururaceae & 2 & 2 & 1.4 & 0.6 \\
Datiscaceae & 1 & 1 & 1.3 & -0.3 \\
Zingiberaceae & 1 & 0 & 1.3 & -1.3 \\
Agavaceae & 86 & 0 & 11 & -11 \\
Fabaceae & 1225 & 108 & 138 & -30 \\
\hline
\end{tabular}

-FNASPE $=$ Number of species in Flora North America.

'MPSPE = Number of medicinal species in North America.

duce substances that have medicinal value for human beings, and how those substances vary between taxa. In the simplest terms, plants seem to produce chemicals which are biologically active to enhance their own survival (Levin, 1976; Spencer, 1988). They produce herbicides to inhibit the growth of competing plants. Salicylic acid (precursor of aspirin) is a water soluble phytotoxin which washes off the leaves of willows (and other plants) to the ground below, inhibiting plant growth (Bell, 1981). Juglone, produced by black walnut trees, does the same thing.

Plants also produce substances which deter browsing by insects and other herbivores (Rosenthal and Janzen, 1979). A classic case involves the relationship between grasses and grazing mammals: "Plants in these systems rely primarily on physical defenses (sharp awns, high silica content), growth form, and compensatory growth rather than chemicals for defense" (Lindroth, 1988). Most relevant here are plants which produce loxic or repellent chemicals. Some familiar botanical insecticides are nicotine and the pyrethrins. In certain cases, herbivores have adapted to these defenses. A well known case is that of the monarch butterflies (Danaus plexippus L.); the larvae feed on otherwise toxic milkweeds (Asclepias spp.), ingesting and sequestering varlous cardiac glycosides, thereby in turn deterring various birds from feeding on them (Brower et al., 1988). Similarly, pines are generally protected against a variety of both insects and fungi by the pitch they exude from both xylem and leaves. Protection against insects is both physical (the sticky pitch drowns them) and chemical (the monoterpenes in pitch are toxic to many insects). However, several species of bark beetles (Dendroctonus spp.) can detoxify these substances and even utilize them as pheromones which "serve to recruit the large number of beetles needed to overcome the physical resistance of the tree" (Renwick, 1988, p. 307). The human use of bioactive botanical substances as medicines is analogous to these insect adaptations and that principle will inform the subsequent analysis. 


\section{Results}

A. Subclasses of the North American flora

The first application of the method of residual analysis was on a high order classification of the data, dividing the materials into 12 different groups called subclasses. As with families, data from the two sources indicated earlier were utilized in the following fashion: the data on the plants of North America are from FNA and the data on medicinal plants are from MPNA.

\section{a. The subclasses}

The initial analysis is at a high taxonomic level referred to as the subclass level, even though not all the levels are technically subclasses. Table 2 lists these units, in boldface, in the context of a larger classification based on the work of Cronquist (1968). Even though the taxon Pteridophyta is technically a "division" while Gymnospermae is a "subdivision" (Fernald, 1970), they, along the with the "proper" subclasses (Magnoliidae, Hamamelidae, etc.) (Cronquist, 1968) will all be referred to as "subclasses". The table also lists

\section{TABLE 2}

SUBCLASSES IN FLORA NORTH AMERICA (FNA) AND MEDICINAL PLANTS OF NATIVE AMERICA (MPNA)

\begin{tabular}{|c|c|c|c|c|c|}
\hline \multirow[t]{2}{*}{ Plant groups } & \multicolumn{3}{|l|}{ FNA } & \multicolumn{2}{|l|}{ MPNA } \\
\hline & Families & Genera & Species & Genera & Species \\
\hline $\begin{array}{l}\text { I. Pteridophyta } \\
\text { II. Spermatophyta }\end{array}$ & 14 & 61 & 340 & 21 & 49 \\
\hline $\begin{array}{l}\text { A. Gymnospermae } \\
\text { B. Angiospermae } \\
\text { 1. Dicotyledoneae }\end{array}$ & 6 & 19 & 118 & 15 & 59 \\
\hline i. Magnoliidae & 16 & 87 & 507 & 44 & 110 \\
\hline ii. Hamamelidae & 11 & 37 & 272 & 25 & 80 \\
\hline iii. Caryophyllidae & 14 & 163 & 1335 & 43 & 138 \\
\hline iv. Dilleniidae & 44 & 284 & 1591 & 87 & 223 \\
\hline v. Rosidae & 54 & 509 & 3637 & 182 & 521 \\
\hline $\begin{array}{l}\text { vi. Asteridae } \\
\text { 2. Monocotyledoneae }\end{array}$ & 36 & 718 & 5088 & 226 & 722 \\
\hline 1. Alismatidae & 9 & 29 & 104 & 4 & 6 \\
\hline ii. Commelinidae & 14 & 262 & 2431 & 37 & 72 \\
\hline iii. Arecidae & 3 & 28 & 47 & 6 & 8 \\
\hline iv. Liliidae & 11 & 158 & 800 & 45 & 107 \\
\hline Total & 232 & 2355 & 16270 & 735 & 2095 \\
\hline
\end{tabular}


the number of families, genera and species in FNA and the number of medicinally used genera and species (those in MPNA) for each of the subclasses.

\section{b. Regression analysis of subclasses}

Do the different subclasses provide medicinal species with the same frequency? Using the method described previously, a regression analysis was performed on these 12 subclasses. The regression equation showing the relation between the number of species in each subclass (FNASPE) and the number of them used medicinally (MPSPE) is

\section{MPSPE $=1.25+0.128 \times$ FNASPE}

The data as well as the predicted and residual values are shown in Table 3. They are also displayed graphically in Fig. 1 where the points plotted are the actual values of the number of species and of medicinal species in each subclass, while the line drawn represents all the points predicted by the regression equation. The residual is represented by the vertical distance between the plotted point and the regression line.

\section{c. Analysis of the residuals}

The residuals in this analysis are highly variable, ranging from 70 to -240 (see Fig. 2). As percentages of predicted values, the residuals range from $-77 \%$ to $261 \%$; the mean of the absolute values of those percentages is $55 \%$. How can these numbers be grouped so that some can be said to be "farther from the regression line" than others? The standard deviation of a set of values provides a measure of its "spread"; as these are census

TABLE 3

RESIDUAL ANALYSIS OF 12 SUBCLASSES

\begin{tabular}{lrrrr}
\hline Subclass & FNASPE & MPSPE & Predicted & Residual $^{\mathrm{a}}$ \\
\hline Asteridae & 5088 & 722 & 651.7 & 70.3 \\
Rosidae & 3637 & 521 & 466.2 & 54.8 \\
Hamamelidae & 272 & 80 & 36.0 & 44.0 \\
Magnoliidae & 507 & 110 & 66.1 & 43.9 \\
Gymnospermae & 118 & 59 & 16.3 & 42.7 \\
Dilleniidae & 1591 & 223 & 204.6 & 18.4 \\
Pteridophyta & 340 & 49 & 44.7 & 4.3 \\
Liliidae & 800 & 107 & 103.5 & 3.5 \\
Arecidae & 47 & 8 & 7.3 & 0.7 \\
Alismatidae & 104 & 6 & 14.5 & -8.5 \\
Caryophyllidae & 1335 & 138 & 171.9 & -33.9 \\
Commelinidae & 2431 & 72 & 312.0 & -240.0 \\
\hline
\end{tabular}

-Standard deviation of 12 residuals is 77.9 . 




Fig. 1. Regression plot of twelve subclasses showing medicinal species versus total species. The points plotted are the actual values of the number of species and medicinal species in each sublcass. The residual value is represented by the vertical distance from the point to the regression line. The three marked points (Ast, Ros, Com) represent values with residuals greater than the standard deviation of the set.

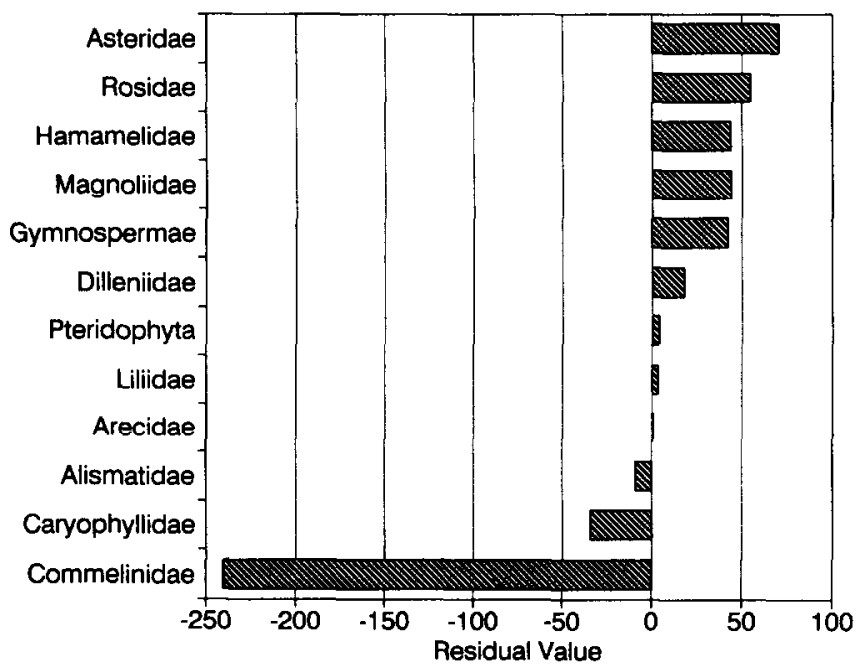

Fig. 2. Regression residuals of twelve subclasses. 
data the population standard deviation is used. The standard deviation of the collection of the 12 residuals is 77.9; only one value in the set, for Commelinidae, is greater than that figure, demonstrating what also seems clear by inspection, that this value is distinctively different from the rest. The substantive version of this statistical statement is that, given its size, the Commelinidae produce far fewer medicinal species for Native Americans than do any of the other subclasses.

\section{d. Second regression analysis}

To continue partitioning the values, the entire analysis is repeated after eliminating the value for Commelinidae from the set. The new regression equation is:

$$
\text { MPSPE }=10.02+0.138 \cdot \text { FNASPE }
$$

The associated predicted and residual values are shown in Table 4. The standard deviation of the 11 residuals is 25.3. Now there are 4 subclass residuals which exceed the standard deviation, three positively (Gymnospermae, Hamamelidae and Magnolidae) and one negatively (Caryophyllidae). While these are not outliers in the way that Commelinidae was, they are clearly plant groups which provide either more than or less than their share of medicinal plants.

\section{e. The subclass Hamamelidae}

The subclass Hamamelidae is subjected to further analysis. This subclass has been selected for analysis because it ranks high on the scale of medicinal subclasses (third in Table 3, second in Table 4) and yet is of modest size. It

TABLE 4

RESIDUAL ANALYSIS OF 11 SUBCLASSES

\begin{tabular}{lcrrr}
\hline Subclass & FNASPE & MPSPE & Predicted & Residuala $^{\text {a }}$ \\
\hline Gymnospermae & 118 & 59 & 26.3 & 32.7 \\
Hamamelidae & 272 & 80 & 47.6 & 32.4 \\
Magnoliidae & 507 & 110 & 80.1 & 29.9 \\
Asteridae & 5088 & 722 & 713.3 & 8.7 \\
Rosidae & 3637 & 521 & 512.7 & 8.3 \\
Dilleniidae & 1591 & 223 & 229.9 & -6.9 \\
Pteridophyta & 340 & 49 & 57.0 & -8.0 \\
Arecidae & 47 & 8 & 16.5 & -8.5 \\
Liliidae & 800 & 107 & 120.6 & -13.6 \\
Alismatidae & 104 & 6 & 24.4 & -18.4 \\
Caryophyllidae & 1335 & 138 & 194.5 & -56.5 \\
\hline
\end{tabular}

aStandard deviation of 11 residuals is 25.3. 
TABLE 5

FAMILIES OF THE SUBCLASS HAMAMELIDAE, EXTRACTED FROM APPENDIX A

\begin{tabular}{|c|c|c|c|c|c|}
\hline Rank & Family & FNASPE & MPSPE & Predicted & Residual \\
\hline 10 & Corylaceae & 33 & 21 & 4.9 & 16.1 \\
\hline 15 & Fagaceae & 140 & 26 & 16.8 & 9.2 \\
\hline 25 & Juglandaceae & 25 & 9 & 4.0 & 5.0 \\
\hline 32 & Urticaceae & 17 & 7 & 3.1 & 3.9 \\
\hline 50 & Ulmaceae & 18 & 5 & 3.2 & 1.8 \\
\hline 51 & Moraceae & 19 & $\mathbf{5}$ & 3.3 & 1.7 \\
\hline 58 & Myricaceae & 8 & 3 & 2.1 & 0.9 \\
\hline 68 & Platanaceae & 4 & 2 & 1.7 & 0.3 \\
\hline 69 & Hamamelidaceae & 4 & 2 & 1.7 & 0.3 \\
\hline 116 & Leitneriaceae & 1 & 0 & 1.3 & -1.3 \\
\hline \multirow[t]{2}{*}{157} & Casuarinaceae & 3 & 0 & 1.6 & -1.6 \\
\hline & Total & 272 & 80 & & \\
\hline
\end{tabular}

contains 11 families with a total of 272 species in North America, of which 80 are used medicinally. The subclass is named after the family Hamamelidaceae which contains the genus Hamamelis, or witch hazel, a classic medical species.

The subclass Hamamelidae is comprised of 11 families of varying sizes. Table 5 lists them in the order they appear in Appendix A, which is based on the overall regression of MPNA species on FNA species.

The table shows that Corylaceae and Fagaceae are the most prominent sources of medicinal species from this already well represented subclass. Table 6 lists the genera of these two families. It is interesting to note that these are all trees; moreover, most of them are clear sources of resins or tannin, useful for a variety of medical purposes (Swain, 1979).

TABLE 6

GENERA OF CORYLACEAE AND FAGACEAE

\begin{tabular}{lllr}
\hline Family & Genus & & Uses \\
\hline Corylaceae & Alnus & Alder & 118 \\
& Betula & Birch & 53 \\
& Carpinus & Hornbeam & 13 \\
& Corylus & Hazel & 25 \\
Fagaceae & Ostrya & Hop hornbeam & 16 \\
& Castanea & Chestnut & 20 \\
& Fagus & Beech & 13 \\
& Lithocarpus & Tanbark & 2 \\
& Quercus & Oak & 215 \\
\hline
\end{tabular}




\section{f. Indications and therapeutic categories}

The original database classifies the usage of medicinal species into a set of 73 "indications" ranging from "abortifacient" to "witchcraft medicine" and includes others such as analgesic, cancer treatment, hemostat and the like (Moerman, 1986). In the current analysis, these 73 categories are collapsed into a set of 10 larger units called "therapeutic categories". Table 7 summarizes these categories and Appendix B lists the frequency of each of the 73 indications by category. Each category has a three-letter code for use in tables, etc.

\section{g. The usage of the Hamamelidae}

Different subclasses and families are used in different ways. Table 8 shows the usage of the different therapeutic categories for each of the 11 families in the subclass Hamamelidae. The families are ranked by their total number of uses, while the therapeutic categories are ordered in terms of their overall frequency as in Table 7.

A glance at Table 8 demonstrates some of the difficulties inherent in an analysis like this. The subclass Hamamelidae was selected for this analysis because it is relatively small with only 11 families. The 73 indications were collapsed into 10 categories. Yet, Table 8 has 110 cells. How might more or less "interesting" cases of use be selected for closer analysis? All 110 cases could be considered in turn. But since there are 232 families represented in the data, by that strategy 2320 different combinations would ultimately have to be considered. This would be impractical and unreadable. Therefore, a way must be found to sort the cases in some fashion.

The procedure is essentially the same as before. A series of regression analyses is carried out, this time by selecting the number of medicinal spe-

\section{TABLE 7}

FREQUENCY OF THE 10 THERAPEUTIC CATEGORIES IN THE DATABASE

Type of treatment

General (GEN)

Cardiological (CAR)

Orthopedic (ORT)

Oto-Rhino-Laryngological (OTO)

Pulmonary (PUL)

Neurological (NEU)

Gynecological-Urinary (GYN)

Dermatological (DER)

Gastro-Intestinal (GIM)

Other (OTH)
Frequency

$$
\begin{array}{r}
218 \\
404 \\
756 \\
1014 \\
1346 \\
1774 \\
1761 \\
2043 \\
2848 \\
3679
\end{array}
$$


TABLE 8

USES OF HAMAMELIDAE BY FAMILY AND THERAPEUTIC CATEGORY

\begin{tabular}{lrrrrrrrrrrrr}
\hline Family & \multicolumn{1}{l}{ Therapeutic category } \\
\cline { 2 - 13 } & GEN & CAR & ORT & OTO & PUL & NEU & GYN & DER & GIM & OTH & Total \\
\hline Fagaceae & 1 & 6 & 11 & 21 & 21 & 18 & 22 & 31 & 48 & 42 & 221 \\
Corylaceae & 6 & 11 & 7 & 10 & 15 & 14 & 27 & 23 & 60 & 31 & 204 \\
Juglandaceae & 1 & 4 & 5 & 8 & 3 & 6 & 9 & 15 & 35 & 15 & 101 \\
Urticaceae & 1 & 1 & 17 & 0 & 6 & 12 & 13 & 8 & 9 & 25 & 92 \\
Ulmaceae & 0 & 1 & 1 & 12 & 15 & 3 & 18 & 9 & 23 & 6 & 88 \\
Moraceae & 1 & 0 & 1 & 5 & 2 & 14 & 7 & 4 & 15 & 7 & 56 \\
Hamamelidaceae & 1 & 2 & 5 & 3 & 5 & 5 & 6 & 7 & 8 & 10 & 52 \\
Myricaceae & 1 & 1 & 2 & 1 & 3 & 8 & 4 & 9 & 5 & 5 & 39 \\
Platanaceae & 1 & 1 & 1 & 1 & 5 & 1 & 5 & 4 & 9 & 7 & 35 \\
Casuarinaceae & 0 & 0 & 0 & 0 & 0 & 0 & 0 & 0 & 0 & 0 & 0 \\
Leitneriaceae & 0 & 0 & 0 & 0 & 0 & 0 & 0 & 0 & 0 & 0 & 0 \\
& & & & & & & & & & & \\
Total & 13 & 27 & 50 & 61 & 75 & 81 & 111 & 110 & 212 & 148 & 888 \\
& & & & & & & & & & & \\
\hline
\end{tabular}

-Values in italics are substantially above the predicted values.

cies per family (MPSPE) as the independent variable and the number of uses for a particular category of treatment as the dependent variable. Table 9 shows the analysis for gastro-intestinal medicines (GIM) in the Hamamelidae. The regression equation is

$$
\mathrm{GIM}=3.55+2.16 \times \mathrm{MPSPE}
$$

The second row in the table shows that the family Corylaceae has 21 medicinal species which are used in 60 different ways to treat gastro-intestinal problems of some sort. However, the regression predicted that there were only 48.9 such uses. This gives a residual of 11.1 more uses than was predicted if all usage were random and simply a consequence of frequency. The standard deviation of the residuals is 7.5; again this gives a convenient way to partition the set of values. Table 9 shows that Juglandaceae, Corylaceae and Ulmaceae produce more than the expected number of gastro-intestinal medicines while Fagaceae and Urticaceae produce fewer. Referring back to Table 8 note that the values in the GIM column for Corylaceae, Juglandaceae and Ulmaceae are in italics. This is to indicate that the values of 60,35 and 23 are substantially above (e.g., more than one standard deviation above) the predicted values under the assumption of randomness. Sixteen such cases are marked in that table. Note further that four of the 16 cases are for the family Corylaceae, for general medicines (GEN), cardiological medicines (CAR), gynecological-urinary medicines (GYN) and gastro-intestinal 
TABLE 9

REGRESSION OF GASTRO-INTESTINAL MEDICINES ON MEDICINAL SPECIES BY FAMILY IN HAMAMELIDAE

\begin{tabular}{lrrrr}
\hline Family & & \multicolumn{2}{l}{ GIM } & \\
\cline { 2 - 5 } & MPSPE & Actual & Predicted & Residual' \\
\hline Juglandaceae & 9 & 35 & 23.0 & 12.0 \\
Corylaceae & 21 & 60 & 48.9 & 11.1 \\
Ulmaceae & 5 & 23 & 14.4 & 8.6 \\
Platanaceae & 2 & 9 & 7.9 & 1.1 \\
Moraceae & 5 & 15 & 14.4 & 0.6 \\
Hamamelidaceae & 2 & 8 & 7.9 & 0.1 \\
Casuarinaceae & 0 & 0 & 3.6 & -3.5 \\
Leitneriaceae & 0 & 0 & 3.6 & -3.5 \\
Myricaceae & 3 & 5 & 10.0 & -5.0 \\
Urticaceae & 7 & 9 & 18.7 & -9.7 \\
Fagaceae & 26 & 48 & 59.8 & -11.8 \\
\hline
\end{tabular}

"Standard deviation of the residuals is 7.5.

medicines (GIM). Corylaceae by this measure is an "interesting" family, worth closer examination.

This analysis produces a total of 110 residual values. It is worth noting that the largest residual in the set applies to the family Urticaceae for orthopedic medicines (ORT). Seven medicinal species had 17 orthopedic uses even though the predicted number of such uses was 4.4; this gives a residual of 12.6. Urticaceae is clearly another interesting family to examine.

\section{h. Corylaceae}

According to FNA, there are 33 species of Corylaceae in North America divided among five genera (Alnus, Betula, Carpinus, Corylus and Ostrya). Most of them are native trees although some are shrubs and a few are introduced.

Referring back to Table 8, note that Corylaceae had substantial usage in 4 therapeutic categories: general, cardiological, gynecological-urological and gastro-intestinal medicines. Table 10 shows all the medicinal usage of these five genera by category; the four substantial usage categories are in bold face.

Consider first the cardiological medicines. There are eleven uses for the Corylaceae in this category. Most of these are classified in MPNA as "blood medicines". Some examples include the Chippewa use of an infusion of bark of Alnus incana (L.) Moench for "anemia" and the Cherokee use of the bark of $A$. serrulata (Ait.) Willd. to "purify the blood".* The Iroquois, Ojibwa and Montagnais are among other groups who make similar uses of these species.

*See Moerman, 1986, for complete bibliographic information for these and all subsequent ethnobotanical references. 
TABLE 10

USES OF CORYLACEAE BY GENUS AND THERAPEUTIC CATEGORY

\begin{tabular}{lrrlll}
\hline & Alnus & Betula & Corylus & Ostrya & Carpinus \\
\hline Gastro-Intestinal & 31 & 16 & 8 & 3 & 2 \\
Other & 15 & 5 & 4 & 3 & 4 \\
Gyn-Urology & 12 & 8 & 1 & 2 & 4 \\
Dermatology & 12 & 3 & 3 & 1 & 3 \\
Neurology & 7 & 6 & 1 & 0 & 0 \\
Pulmonary med & 6 & 5 & 1 & 3 & 0 \\
Cardiology & 5 & 4 & 1 & 1 & 0 \\
Orthopedics & 4 & 1 & 0 & 2 & 0 \\
Oto-Rhino-Lar & 7 & 0 & 2 & 1 & 0 \\
General meds & 2 & 3 & 1 & 0 & 0 \\
& & & & & 13 \\
Total & 118 & 53 & 25 & 16 & 13 \\
\hline
\end{tabular}

The four substantial use categories are in boldface.

Such uses ("purify the blood", "build up the blood", "make the blood warm") are difficult to evaluate; the treatment categories are unfamiliar and hard to translate into a modern idiom. However, there may be a special wisdom in these uses which transcends such specifics. Several species of Corylaceae, especially of the genus Betula, are known to contain significant amounts of "birch oil" of which a chief constituent is methyl salicylate, a precursor of aspirin which has similar effects (Claus et al., 1970). Recent research has shown that very small doses of aspirin reduce the incidence of heart attack in men over 40 (Steering Committee, 1988). It seems possible that methyl salicylate might have an effect on the platelets similar to that of its synthetic cousin.

In this context, another set of uses of Corylaceae is worth noting. The dermatology therapeutic category includes 20 uses of Corylaceae as "dermatological aids". These uses, by groups from the Cree on Hudson's Bay to the Pomo and Swinomish, are mostly as external washes or poultices for cuts, sores, swellings, infections and the like. For example, the Ojibwa used a poultice of the boiled bark of Corylus americana Walt. to help close and heal cuts; the Sanpoil and Swinomish washed sores with a decoction of the bark of Alnus incana (L.) Moench. The value of these procedures may lie in the fact that the salicylates are active disinfectants; the antiseptic properties of salicylic acid are superior to phenol (Lewis and Elvin-Lewis, 1977).

Problems, however, remain. The Potawatomi, Klallam, Quileute and Mendocino Indians all used Alnus species as antidiarrheals. On the other hand, the Iroquois, Cherokee, Bella Coola and Gitksan used Alnus species as laxatives or cathartics; these uses of the same or very closely related plants, by close neighbors, are quite opposite to one another. 
Similarly, several groups (Chippewa, Cherokee, Iroquois, Gitksan, Mendocino Indians) used several species of Alnus as emetics while the Micmac and Penobscot used Alnus bark to treat "retching and cramps", that is, as an antiemetic.

Among 30 or 40 citations of usage for a particular species for one thing or another, it is not uncommon to find that there are a few apparently contradictory uses. Depending on how the case is phrased, however, these may not be contradictory at all: both dextroamphetamine and methylphenidate are central nervous system stimulants but both are widely used to calm hyperactive children. These opposite uses may be labeled "paradoxical" rather than contradictory (Goodman and Gilman, 1970). In other cases, different uses might be labeled "orthogonal", as in the usage of the antihistamine diphenhydramine hydrochloride $\left(B^{2}\right.$ adryl $\left.{ }^{\circledR}\right)$ in over-the-counter sleeping preparations; when used as an antihistamine, the drowsiness induced is referred to as a "side effect" (Romanucci-Ross and Moerman, 1988). Again, other cases might be labeled "linguistic" or "categorical" differences, as in the use of aspirin for "colds" and "headaches", which might seem to be quite different ailments.

The uses of Alnus described here do not appear to be obvious cases of these more benign theoretical alternatives. Indeed, it is not clear that the plants would have any constituents to recommend them on the one hand as either emetics or antiemetics, or, on the other, as either cathartics or antidiarrheals. Clearly the "interesting cases" elicited by this method are not all simple ones; much complex work still remains before we will understand all the dimensions of Native American medicine.

\section{i. Urticaceae}

According to FNA, there are 17 species of Urticaceae in North America divided into 6 genera (Laportea, Pilea, Urtica, Boehmeria, Hesperocnide, and Parietaria) of which the first three provide medicinal species. The uses of these three genera are listed in Table 11. The most widely used genus is Urtica, the nettles. The "other" category in this case is quite literal, comprising a series of highly variable uses ranging from tonics to witcheraft medicines with no obvious pattern.

There is, however, an interesting pattern in the next two categories, orthopedics and neurology. The preponderance of these cases are ones where various species of nettles are used as counter-irritants or "liniments" for various sorts of pain, usually of the muscles or joints, or, more specifically, for "rheumatism". There are at least 16 such cases of which these are typical.

- The Bella Coola used Urtica lyallii S. Wats. to sting paralyzed limbs; likewise, they used the plant in the sweat bath for rheumatic pains.

- The Chehalis and the Quileute used the stalk of Urtica dioica L. to whip rheumatic limbs; the latter also drank an infusion of the pounded roots for rheumatism. 
USES OF SELECTED URTICACEAE BY GENUS AND THERAPEUTIC CATEGORY

\begin{tabular}{lcll}
\hline & Urtica & Laportea & Pilea \\
\hline Other & 20 & 4 & 1 \\
Orthopedics & 17 & 0 & 0 \\
Neurology & 11 & 1 & 0 \\
Gyn-Urology & 8 & 5 & 0 \\
Gastro-intestinal & 7 & 1 & 1 \\
Dermatology & 7 & 0 & 1 \\
Pulmonary med & 5 & 0 & 1 \\
Cardiology & 1 & 0 & 0 \\
General meds & 1 & 0 & 0 \\
Oto-Rhino-Lar & 0 & 0 & 0 \\
& & & 4 \\
Total & 77 & 11 & \\
\hline
\end{tabular}

- The Shoshone applied a hot poultice of the leaves of Urtica gracilis Ait. to rheumatic joints.

The dermatological uses of Urtica are different, possibly reflecting homeopathic theories as the genus is reportedly used to treat itching toes, heat rash, hives and sores. These dermatological and orthopedic uses of the Urticaceae probably follow from the quality that this family (and several others, notably Euphorbiaceae, Loasaceae and Hydrophyllaceae) have of producing contact dermatitis ("urtication") with stinging hairs.

"On contact, the tip of the hair breaks off, and its contents are injected into the skin of the [browsing] animal. In some plant species, the contents include acetylcholine, histamine, and 5hydroxytryptamine. . . The effect of the sting in most instances is to cause a local flare on the skin surface and a local increase in skin temperature due to the dilation of arterioles" (Chapman and Blaney, 1979).

Related reports indicate that the $\mathrm{Kwakiutl}$ rub the juice of Urtica dioica into the scalp to prevent hair from falling out; similarly, the Skokomish use a decoction of the roots as a hair wash (Turner and Bell, 1973). Urtica may have dermatological effects analogous to those of the hypotensive drug minoxidil which causes relaxation of smooth muscle leading to increased blood flow to the scalp which may be indicated in the effectiveness of this drug in stimulating hirsutism (De Villez, 1985; see also De Villez, 1988).

Finally, a pattern appears among the gynecological and urinary medicines. Table 12 lists six uses by as many cultural groups of two species of Urticaceae, all to facilitate childbirth. These items were collected by several different authors over a period of a generation or more. Various species of Urtica have been shown to contain betaine as well as 5-hydroxytryptamine, both of which can stimulate uterine tissue in vitro and in vivo (Farnsworth et al., 1975). These species may have some influence on uterine contraction. 
TABLE 12

GYNECOLOGICAL USAGE OF URTICACEAE*

Laportea canadensis

Iroquois

Urtica dioica

Cowlitz

Kwakiutl

Lummi

Quinault

Squaxin
Infusion of smashed roots taken to facilitate childbirth.

Infusion of nettles taken by women about to deliver a child.

Plant juice taken by pregnant women who are overdue.

Infusion of nettles taken by women to relax the muscles during childbirth.

Tips of the plant chewed by women during labor.

Infusion of crushed leaves taken by women having difficulties in labor.

-For references, see Moerman (1986).

\section{j. Commelinidae}

As noted earlier, the subclass Commelinidae produces by far the fewest medicinal plants. A virtue of the method of residual analysis is that it allows easy identification of such ignored groups as well as heavily utilized ones. Table 13 lists the families of this subclass in the order they appear in Appendix $A$, which is based on the overall regression of MPNA species on FNA species; this is comparable to Table 5 showing the families of the Hamamelidae suborder. Less than $3 \%$ of the species of this large group are used

TABLE 13

FAMILIES OF THE SUBCLASS COMMELINIDAE, EXTRACTED FROM APPENDIX A

\begin{tabular}{rlrcrr}
\hline RANK & FAMILY & FNASPE & MPSPE & Predicted & Residual \\
\hline 70 & Typhaceae & 4 & 2 & 1.6 & 0.4 \\
106 & Musaceae & 1 & 0 & 1.3 & -1.3 \\
135 & Zingiberaceae & 1 & 0 & 1.3 & -1.3 \\
139 & Mayacaceae & 2 & 0 & 1.4 & -1.4 \\
154 & Cannaceae & 3 & 0 & 1.5 & -1.5 \\
149 & Marantaceae & 3 & 0 & 1.5 & -1.5 \\
155 & Sparganiaceae & 12 & 1 & 2.5 & -1.5 \\
167 & Commelinaceae & 40 & 4 & 5.6 & -1.6 \\
185 & Xyridaceae & 17 & 1 & 3.0 & -2.0 \\
193 & Eriocaulaceae & 10 & 0 & 2.3 & -2.3 \\
196 & Bromeliaceae & 20 & 1 & 3.4 & -2.4 \\
228 & Juncaceae & 123 & 4 & 14.9 & -10.9 \\
231 & Cyperaceae & 718 & 22 & 81.2 & -59.2 \\
232 & Poaceae & 1477 & 37 & 165.9 & -128.9 \\
& & & & & \\
& Total & 2431 & 72 & & \\
\hline
\end{tabular}


medicinally. The predominant family in the subclass is the Poaceae, the grass family. Only $2.5 \%$ of the species in this huge family - with nearly $10 \%$ of the species of the continent - are used medicinally. Note however that Poaceae is the primary source of human foods - wheat, corn, oats, rye and barley are among the seed grains that feed most people and their domesticated animals. As has already been noted, the Poaceae generally do not depend on chemicals for defense against predation (Lindroth, 1988). As such, human beings have adopted them for foods, not drugs.

Since the family is so large, it is not surprising to find exceptions to the general principle. Several species of the genus Andropogon, bluestem, are used as analgesics, diuretics, stimulants and the like and are administered internally by the Chippewa, Omaha, Comanche, Houma, Catawba and others. One species, Andropogon nardus L., produces the fragrant oil citronella which is to some degree toxic or noxious to insects indicating bioactivity (Claus et al., 1970); related species may produce similar substances.

\section{B. Variable usage among families}

There are other ways that these data can be manipulated to elicit interesting subgroups. This section shows another variation on the theme of regression and residual analysis to elicit such material. First, a series of ten regressions was calculated. In each case, the regression was of the number of uses of a particular family for a particular therapeutic category on the total number of uses of that family. For example, the regression of the number of uses as gastro-intestinal medicines (GIM-Uses) on total uses (Uses) gives this equation:

$$
\text { GIM-Uses }=0.621+0.171 \times \text { Uses }
$$

Table 14 shows the ten families with the largest residuals in that regression. Given the total number of uses of the Rosaceae, one would predict that 178 would be for gastro-intestinal illnesses; but, in fact, 253 were so used, giving a residual of 75 .

As noted, this process was repeated for each of the 10 therapeutic categories. Rosaceae, which ranks first in the regression of the gastro-intestinal uses, ranks last in the regression of neurological medicines. It also ranks last in the orthopedic medicine and the general medicine categories. Thus, these rankings can vary quite dramatically for a given plant family. A simple way to measure this variation is to calculate the standard deviation of the 10 rankings for each family. Table 15 shows all ten rankings for the 15 families with the greatest standard deviations.

Lamiaceae, the mint family, ranks first in this table. Note that Lamiaceae ranks last - with a ranking of 232 - in four different categories (DER, GYN, OTO and OTH) and next to last in one more (ORT). At the other end of the scale, the same family ranks 13th in one (GEN), fourth in two (GIM and 
TABLE 14

REGRESSION ANALYSIS OF GASTRO-INTESTINAL USES ON TOTAL USES

\begin{tabular}{|c|c|c|c|c|c|}
\hline \multirow[t]{2}{*}{ Rank } & \multirow[t]{2}{*}{ Family } & \multicolumn{4}{|l|}{ Uses } \\
\hline & & Total & GIM & Predicted & Residual \\
\hline 1 & Rosaceae & 1038 & 253 & 177.77 & 75.23 \\
\hline 2 & Rhamnaceae & 132 & 48 & 23.15 & 24.85 \\
\hline 3 & Corylaceae & 204 & 60 & 35.44 & 24.56 \\
\hline 4 & Lamiaceae & 645 & 135 & 110.70 & 24.30 \\
\hline 5 & Caprifoliaceae & 404 & 90 & 69.57 & 20.43 \\
\hline 6 & Juglandaceae & 101 & 35 & 17.86 & 17.14 \\
\hline 7 & Polygonaceae & 350 & 73 & 60.35 & 12.65 \\
\hline 8 & Berberidaceae & 121 & 33 & 21.27 & 11.73 \\
\hline 9 & Gentianaceae & 65 & 23 & 11.71 & 11.29 \\
\hline 10 & Scrophulariaceae & 324 & 67 & 55.92 & 11.08 \\
\hline
\end{tabular}

CAR) and first in two more (NEU and PUL) therapeutic categories. Again, using regression, these families can be sorted in interesting ways. The usage of Lamiaceae will be examined below.

Another interesting aspect of this table is that, generally speaking, the patterns taken by the different families are all different from one another. The two families with the most similar patterns are Rosaceae and Caprifoli-

TABLE 15

FAMILIES AND THEIR RANKINGS IN 10 REGRESSIONS

\begin{tabular}{|c|c|c|c|c|c|c|c|c|c|c|c|c|}
\hline \multirow[t]{2}{*}{ Rank } & \multirow[t]{2}{*}{ Family } & \multicolumn{10}{|c|}{ Ranking by therapeutic category } & \multirow[b]{2}{*}{ S.D." } \\
\hline & & GIM & NEU & PUL & DER & GYN & ORT & оTO & CAR & GEN & OTH & \\
\hline 1 & $\mathrm{Lg}$ & 4 & 1 & 1 & 232 & 232 & 231 & 232 & 4 & 13 & 232 & 3.64 \\
\hline 2 & Apia & 228 & 229 & 7 & 222 & 229 & 3 & 24 & 228 & 4 & 1 & 09.87 \\
\hline 3 & Rosaceae & 1 & 232 & 197 & 29 & 7 & 232 & 6 & 5 & 232 & 231 & 108.28 \\
\hline 4 & Capr: & 5 & 223 & 232 & 231 & 1 & 216 & 7 & 11 & 231 & 219 & 107.59 \\
\hline 5 & Solan & 70 & 5 & 229 & 14 & 231 & 229 & 2 & 231 & 230 & 2 & 107.30 \\
\hline 6 & Faba & 38 & 7 & 231 & 216 & 227 & 221 & 4 & 219 & 15 & 5 & 104.96 \\
\hline 7 & Lilia & 231 & 226 & 226 & 3 & 8 & 1 & 198 & 207 & 23 & 15 & 104.35 \\
\hline 8 & Arac & 217 & 6 & 5 & 229 & 230 & 20 & 11 & 37 & 1 & 222 & 103.93 \\
\hline 9 & Poly & 7 & 225 & 228 & 10 & 196 & 13 & 223 & 3 & 229 & 216 & 103.89 \\
\hline 10 & Scrol & 10 & 227 & 9 & 203 & 206 & 224 & 231 & 20 & 228 & 6 & 102.60 \\
\hline 11 & Ast & 230 & 2 & 206 & & 210 & 9 & 226 & 232 & 218 & 8 & 102.34 \\
\hline 12 & Cory & 3 & 224 & 201 & 205 & 19 & 220 & 216 & 6 & 6 & 230 & 102.03 \\
\hline 13 & Pinaceae & 229 & 231 & 2 & 1 & 216 & 2 & 229 & 229 & 205 & 227 & 102.03 \\
\hline 14 & Anacardiaceae & 68 & 228 & 218 & 4 & 30 & 230 & 17 & 230 & 211 & 9 & 100.37 \\
\hline 15 & Cupressaceae & 232 & 177 & 3 & 230 & 10 & 7 & 224 & 36 & $\mathbf{5}$ & 31 & 99.73 \\
\hline
\end{tabular}

"Standard deviation. 
aceae, ranked 3 and 4 in the table. In any category where one ranks high (low), so does the other, with one exception: Rosaceae ranks 29th in the DER category while Caprifoliaceae ranks 231 (see Table 16). Likewise, Pinaceae and Asteraceae are generally the same, except for differences in the categories NEU, PUL and OTH.

Conversely, the Lamiaceae and Liliaceae are nearly opposites. When one is high the other is low, or vice versa, except for the categories OTO (both are low) GEN (both are high). Another pair of opposites is Solanaceae and Cupressaceae; this case is less clear, however, since Solanaceae is intermediate on GIM (ranked 70th), not extreme.

The Corylaceae, discussed earlier, shows up here in position 12; as earlier, the family ranks high in the areas GIM, GYN, CAR and GEN. In the next few sections several of these interesting families will be examined briefly.

\section{a. Lamiaceae}

The family Lamiaceae ranks high by this analysis in several categories. The family ranks first in neurological aids and pulmonary aids. The "neurological aid" category, with 1774 items, is comprised in large part of pain remedies of various sorts, especially the indication "analgesic" with 938 items. The "pulmonary aid" category, with 1346 items, is substantially comprised of the "cold remedy" indication with 528 items. In the case of Lamiaceae, there appears to be an overlap of the two categories. A substantial proportion of the analgesic items for Lamiaceae are for relief of pain associated with "colds". For example, the Chippewa use an infusion of the root of Agastache foeniculum (Pursh) Kunze, elk mint, for cold and chest pain; the Gosiute use a decoction of Mentha arvensis L. for coughs and colds with headache. Both of these are classified as analgesic in the database. There are also many uses of these species for colds which may not include pain. The Dakota, for exam-

\section{TABLE 16}

REGRESSION RANKINGS OF ROSACEAE AND CAPRIFOLIACEAE BY THERAPEUTIC CATEGORY

\begin{tabular}{lcc}
\hline & Caprifoliaceae & Rosaceae \\
\hline GIM & 5 & 1 \\
GYN & 1 & 7 \\
OTO & 7 & 6 \\
CAR & 11 & 5 \\
DER & 231 & 29 \\
PUL & 232 & 197 \\
ORT & 216 & 232 \\
OTH & 219 & 231 \\
NEU & 223 & 232 \\
GEN & 231 & 232 \\
\hline
\end{tabular}


ple, use Hedeoma hispida Pursh, an American pennyroyal, as a treatment for colds, while the Cherokee, Kawaiisu and Rappahannock use Marrubium vulgare L., horehound, for the same purpose.

The medicinal value of the Lamiaceae is probably due primarily to the volatile oils found in many species in the family. Among these are peppermint oil which is the source of menthol, spearmint oil which is an effective carminative and thyme oil which is the source of thymol. These substances, with a number of others like turpentine and camphor, are classed as monoterpenes, widely distributed in the plant world. Monoterpenes and particularly the variability of monoterpene composition of the mints, has been shown to influence herbivory, acting to reduce browsing by slugs (Gould, 1988) and insects (Renwick, 1988).

Thymol has substantial decongestant, antifungal and antibacterial properties and is an anthelmintic especially useful against hookworm (Claus et al., 1970). Menthol stimulates the nerves which perceive cold, but depresses those for pain (Osol and Pratt, 1973); for this reason the substance is an effective antipruritic agent.

\section{b. Apiaceae}

The family Apiaceae, or Umbelliferae, contains a number of familiar plants, among them carrots (Daucus), fennel (Foeniculum), coriander (Coriandrum) and caraway (Carum). Table 17 shows that Apiaceae ranks first in the rather nondescript therapeutic category "other", a case which will be examined below. The family also ranks third in the category of orthopedic medicines, comprised primarily of internal and external treatments for "rheumatism", "arthritis", broken bones, sore limbs, swellings and the like. The preponderance of the 35 uses are of Heracleum maximum Bartr. (11 uses) and Lomatium spp. (9).

The basis of these uses may be due to the widespread presence in species of Apiaceae of various coumarins (see Raichelson, 1986, for a review). Coumarin and related chemicals act as allelopaths by inhibiting seed germination; the chemicals also show a wide range of biological actions including carcinogenic, antibacterial, antispasmodic, analgesic and other activity (Raichelson, 1986). Several studies indicate that coumarins have various antiinflammatory actions (Dunn et al., 1977; Saxena et al., 1982), probably by direct inhibition of prostaglandin production (Lee et al., 1981). This is also the probable mechanism of the salycilates (Gilman et al., 1980); like coumarin, naturally occurring salycilic acid is a phytotoxin (Bell, 1981).

As noted, Apiaceae ranks first in the rather nondescript therapeutic category "other". The largest component of this category for Apiaceae is the much more descriptive indication "poison". A number of these items are not really "medical" but more generally "pharmacognostic" expressing information or knowledge about plants not necessarily used medicinally; for instance, while the Shuswap, Kawaiisu and Kwakiutl all indicate that Cicuta douglasii Coult. et Rose, water hemlock, is known to be poisonous, there is 
no indication that they used it for that purpose, just that it was avoided. Representing the ambiguity many societies grant to medicine and drugs is the testimony of the Ojibwa who note that the root of Pastinaca sativa L., wild parsnip, is very powerful in small amounts, but poisonous in large.

The Iroquois, on the other hand, are reported to chew the roots of water hemlock (Cicuta maculata L.) to commit suicide. They are said further to achieve the same goal by eating the roots of hairy Angelica (Angelica venenosa (Greenway) Fern.). These are the only references to suicide in the database. The authority on Iroquois suicide is William N. Fenton $(1941,1986)$. In his more recent paper, he confirms and amplifies his earlier analysis which indicated that the Iroquois seem to have two basic motivations and methods for suicide: "Type A: poisoning with Cicuta out of some love motive or jealousy, commonly by women; and Type B: violent male suicides by hanging or stabbing out of shame over failure to fulfil some status obligation" (Fenton, 1986, p. 455). While there are "some crossovers as to method by sex and there are two cases of suicide pacts by lovers or spouses" he notes a remarkable consistency in the 45 cases he describes.

There is no doubt that Cicuta is an appropriate plant for this unfortunate purpose. Water Hemlock, C. maculata, is probably the most violently poisonous higher plant of the North Temperate Zone. The toxic principle cicutoxin is a violent convulsant which acts directly on the central nervous system (Claus et al., 1970). Lewis and Elvin-Lewis (1977) note that Cicuta is one of a handful of plants containing toxic resins which are "among the most violent poisons"; Cicuta can pose dangers for both livestock ("fresh root the size of a walnut is reputed to kill healthy cattle") and children (the latter have been poisoned "making peashooters from the hollow stems").

\section{c. Liliaceae}

The largest source of poisonous plants in the database, with 22 items, is not Apiaceae, but Liliaceae, the lily family. The two species most cited as poisonous are the false hellebores (Veratrum spp.) and death camas (Zigadenus spp.). Most of these reports are of the "pharmacognostic" variety, but the Southern Carrier Indians are reported to use Veratrum viride Ait., false hellebore, as an emetic, while recognizing that too strong an infusion may be fatal. Another member of Liliaceae, Amianthemum muscaetoxicum (Walt.) A. Gray, is used by the Cherokee as a poison for crows, as well as for a sure but severe cure for "itch".

Species of Liliaceae contain a variety of alkaloids which are more or less poisonous (Dahlgren et al., 1985); botanists and phytochemists generally account for these substances as devices to prevent or minimize browsing. Common ornamentals like lily of the valley (Convallaria) and daffodils, narcissus and jonquils (Narcissus) contain a variety of complex poisonous substances. Certain species of autumn crocus (Colchicum spp.) produce the toxic alkaloid colchicine, long an effective treatment for gout (Goodman and Gilman, 1970). 


\section{d. Rosaceae and Caprifoliaceae}

As noted, Rosaceae and Caprifoliaceae have nearly identical patterns of usage in the regression analysis, differing only in their popularity for treatments of dermatological conditions. They will be looked at together here (see also Moerman, 1989).

Thorne and Dahlgren agree in the placement of these two families in their systems of classification; both have Rosaceae as a member of the order Rosales in the superorder Rosiflorae, and Caprifoliaceae as a member of the order Dipsacales in the superorder Corniflorae. They also agree on the close relationship between these two superorders by placing them in adjacent positions on their taxonomic maps of the angiosperms (Thorne, 1982; Dahlgren et al., 1982). This similarity is less marked in the treatment of Lewis and Elvin-Lewis (1977).

The two families have a phytochemical similarity in that they are among those which produce significant quantities of cyanogenic glycosides. These chemicals ( 23 have been identified) release cyanide gas when combined with certain enzymes; usually this occurs if the appropriate plant parts (leaves, seeds) are crushed (or chewed). A number of species of Rosaceae (Cotoneaster, Prunus) produce amygdalin while members of Sambucus (Caprifoliaceae) have been shown to produce holocalin, sambunigrin and zierin. All of these taxa (and more) from both families produce prunasin (Jensen and Nielsen, 1973; Conn, 1979).

The two families rank high in the regression analyses in their usage as gastro-intestinal (GIM), gynecological (GYN), oto-rhino-laryngological (ORO) and cardiological (CAR) medicines as shown in Table 16. A few genera account for the preponderance of these uses. Three genera of Caprifoliaceae account for $\mathbf{7 4} \%$ of the uses in those categories while two genera of Rosaceae account for $47 \%$ of them; details are shown in Table 17 .

A substantial number of these uses are accounted for by a few indications of the GIM category. Many uses are as cathartics, emetics and laxatives. Sixty-six of 253 GIM uses of Rosaceae are of these types, while 53 of 90 GIM uses of Caprifoliaceae are. The use of Rosaceae is scattered among 16 genera; the preponderance of usage is of Rubus (15 uses), Purshia (11), Physocarpus (9) and Prunus (7). In most cases, the preparations are in the form of decoctions of root, or bark; it is not clear what active principles may be involved.

The usage of Caprifoliaceae as purgative is less scattered; the genus Sambucus accounts for 37 of 53. Sambucus is an interesting and complex genus which has been in use as a medicinal for thousands of years and all over the world (see, for example, Uphoff, 1968; Hartwell, 1982; Duke and Ayensu, 1985). More recently, a lectin, Sambucus nigra agglutinin (SNA), has been isolated from the plant which has been shown to be of potential value in facilitating bone marrow transplantation (Mumcuoglu et al., 1986); an Asian species, Sambucus formosana Nakai, has been shown to contain several principles which have a protective effect against toxic hepatitis induced by car- 
FREQUENCY OF USE OF IMPORTANT SPECIES OF TWO FAMILIES IN FOUR THERAPEUTIC CATEGORIES

\begin{tabular}{lrrrrr}
\hline & GIM & GYN & OTO & CAR & Total \\
\hline Caprifoliaceae & 56 & 15 & 5 & 5 & 81 \\
Sambucus & 16 & 13 & 6 & 4 & 39 \\
Viburnum & 6 & 18 & 5 & 1 & 30 \\
Lonicera & 12 & 22 & 16 & 2 & 52 \\
All other & 90 & 68 & 32 & 12 & 205 \\
Total & & & & & \\
Rosaceae & 69 & 29 & 19 & 10 & 127 \\
Rubus & 52 & 21 & 20 & 6 & 99 \\
Prunus & 132 & 72 & 32 & 14 & 250 \\
All other & 253 & 122 & 71 & 30 & 476 \\
Total & & & & & \\
\hline
\end{tabular}

bon tetrachloride (Lin and Tome, 1988). One study isolated 19 compounds from the berries (Davidek et al., 1981) while another isolated 56 compounds from the flowers and leaves "including hydrocarbons, esters, carbonyls, alcohols and oxygen- and nitrogen-containing heterocycles" (Velisek et al., 1981). Indeed, Sambucus is such a complex chemical stew, it is hard to infer just what might be operating in any particular situation.

The therapeutic category GYN is a broad one, with a number of different types of uses. The urinary uses comprise four indications (diuretic, kidney aid, urinary aid and venereal aid). Most of the uses of Caprifoliaceae and Rosaceae appear to be intended to facilitate urination and are, broadly, diuretic, although a few are for external application to sores or the like, while others are intended to treat those who "cannot retain urine". There are few obvious patterns here. The use is broadly scattered among a large number of species. Indeed, the 45 uses of "venereal aids" in these two families are spread among 21 genera and 32 species! No species has more than four uses: Cercocarpus ledifolius Nutt. (Mountain mahogany, Rosaceae) is used by the Kawaiisu, Paiute and Shoshone as a treatment for gonorrhea or syphilis internally or externally.

The gynecological aid indication is similarly scattered: 84 uses are spread among 22 genera and 52 species. This is a highly variable indication including a broad range of intentions. Table 18 shows 10 "gynecological" uses of 6 species of the genus Prunus (cherry). Since Prunus sp. has been shown to contain 5-hydroxytryptamine which can stimulate uterine tissue (Farnsworth, et al. 1975), there may be a viable mechanism underlying some of these uses. 
TABLE 18

GYNECOLOGICAL USES OF SIX SPECIES OF GENUS PRUNUS*

$\begin{aligned} & \text { Southern Ojibwa } \\ & \text { Lummi } \\ & \text { Iroquois }\end{aligned}$
The bark is chewed to facilitate childbirth.
An unspecified plant part is added to a compound decoction which is
taken when a woman has a miscarriage.
The stalks are used in a compound decoction which is taken to prevent
hemorrhage after childbirth.
The bark is used in a compound infusion which is taken for
"diseases peculiar to women".
Delaware-Ontario
The bark is used in a decoction which is taken after childbirth as a
strengthening tonic.
A decoction of split roots is taken for blood discharge.
Roots are applied to the nipples of mother to induce the infant to
nurse.
An infusion of bark is taken for childbirth. A warm infusion is given
when labor pains begin.

"For references, see Moerman (1986).

The oto-rhino-laryngological therapeutic category includes ear, mouth, throat, toothache and eye medicines of which the last has the largest group of uses in both families. A separate regression residual analysis of the eyemedicine treatments in the database confirms the significance of Caprifoliaceae and Rosaceae in this area: Caprifoliaceae has the highest residual value, while Rosaceae, with the largest number of uses, is 6 th on the residual list.

The MPNA database includes what seems to be a disproportionately large number of eye medicines and washes. With 346 uses, this is one of the most common indications. The list of uses of several species of the genus Pyrus shown in Table 19 is typical of this large group. Often, the data suggest that the specific intention was to reduce inflammation in the eye. This large number of medicines probably reflects the notion that much of Native Amer-

\section{TABLE 19}

USE OF PYRUS SP. FOR EYE IRRITATIONS*

\begin{tabular}{ll}
\hline Iroquois & $\begin{array}{c}\text { A cold infusion of bark is used as wash for snowblindness and black or } \\
\text { sore eyes. } \\
\text { A compound decoction of bark, inner bark, root or root bark is used as } \\
\text { an eye wash for soreness. } \\
\text { Bella Coola }\end{array}$ \\
Jice, scraped from the peeled trunk, is used as an eye medicine. \\
Klallam & An infusion of bark is used as an eye wash. \\
Quinault & An infusion of bark is used as an eye wash.
\end{tabular}

·For references, see Moerman (1986). 
ican life was spent in the vicinity of smoky fires which resulted in irritated eyes. In contemporary medical practice, treatment for such a condition would probably involve use of corticosteroids (Goodman and Gilman, 1970).

The most commonly used Caprifoliaceae for this purpose were Symphoricarpos spp. Infusions of the leaves or berries were used to wash the eyes by Kwakiutl, Sanpoil, Dakota, Omaha, Ponca and others. The leaves of Symphoricarpos have been shown to contain the sterol beta-sitosterol (Sendra and Janeczko, 1973); sterols are a subclass of the larger group of steroids. The sitosterols have been shown to have anti-inflammatory properties similar to hydrocortisone (Gupta et al., 1980). They are also a constituent of the roots of ginseng (Panax spp.) (Claus et al., 1970) and a number of other plants. What function these chemicals play for the plants is not clear but they would probably make an acceptable substitute for synthetic corticosteroids.

\section{e. Solanaceae}

The Solanaceae is one of the most interesting plant families. It contains a number of species with extremely active and toxic alkaloids, yet also produces a number of important foods; this combination is generally unusual (Moerman, 1989). Among the alkaloids are nicotine, atropine, scopolamine and hyoscamine; among the foods are potatoes, tomatoes and chili peppers. The alkaloids are toxic not only to mammals but also to microorganisms and insects (Levin, 1976).

The family ranks high in the regression rankings in three categories in Table 15. It ranks second in both the oto-rhino-laryngological and "other" categories and fifth in the neurological category. The first case is accounted for largely by the fairly widespread use of three genera (Lycium, Nicotiana and Solanum) as toothache remedies. A representative example is the Navaho use of Lycium spp. as a poultice on an aching tooth; similar cases exist for Shoshone, Tewa, Cherokee, Rappahannock and others. An interesting similar situation occurs in a treatment for toothache currently available in drug stores - small-paper wrapped poultices contain benzocaine and Capsicum, the dried fruit of Capsicum frutescens L., another Solanaceous plant. The counterirritant effect is probably similar in both cases.

More interesting are the cases in the "other" and "neurological" categories. The "other" category is largely accounted for by the indication "ceremonial medicine", while the neurological category is made up largely of analgesics, narcotics and hallucinogens. These uses draw primarily on the psychoactive quality of a number of the Solanaceous alkaloids which act variously as hallucinogens, amnesiacs and narcotics. Native Americans are hardly alone in their use of these chemicals in this way. Several South American species, particularly Brunfelsia, are also hallucinogenic and a number of European species (Atropa, Mandragora, etc.) have had complex and interesting uses for millennia (see Harner, 1973, for a particularly interesting review). 


\section{Analysis by habit groups}

Ethnobiological systems of classification are not usually based on the taxonomist's categories of family, subclass and the like. The standard types of plants in most human languages are "grass", "herb", "shrub", "vine" and "tree", not "Rosaceae", "Caprifoliaceae", etc. (Berlin et al., 1973). We will now briefly examine the distribution of medicinal species based on habit, ignoring botanical classification. Table 20 shows the distribution of FNA and MPNA taxa by habit. The category "forb" refers to all the herbaceous plants except grasses, grass-like plants and the ferns. The "grass-like plants" are those which resemble grasses, but are not in the family Poaceae; most are from the families Cyperaceae and Juncaceae. The Grasses comprise all members of the family Poaceae. Habit is a character which, for some species, might vary with climate or habitat, notably trees and shrubs. But the classification seems generally descriptive of the predominant habit of the taxa.

The table shows the number of species in each habit group listed in both MPNA and FNA. The groups are listed in the order of size of residual; the regression equation is

$$
\text { MPSPE }=-1.2+0.13 \times \text { FNASPE }
$$

The most appropriate comparison for this table is with Table 3 which shows the residuals for 12 subclasses. Figure 3 displays the habit group residuals graphically and can be compared to Fig. 2.

This analysis confirms the observations made earlier about the Commelinidae in general and Poaceae in particular. In this case, taxonomy matches the more obvious qualities of habit. It is interesting that the grass-like plants, mostly sedges and rushes, likewise have a very modest usage. This may

TABLE 20

RESIDUAL ANALYSIS OF SEVEN HABIT GROUPS

\begin{tabular}{lrrrr}
\hline Habit group & MPSPE & FNASPE & Predicted & Residual $^{2}$ \\
\hline Trees & 238 & 894 & 115.0 & 123.0 \\
Shrubs & 363 & 4014 & 260.7 & 102.3 \\
Woody vines & 24 & 132 & 16.0 & 8.0 \\
Ferns and allies & 48 & 341 & 43.1 & 4.9 \\
Forbs & 1359 & 10478 & 1361.1 & -2.1 \\
Grasslike plants & 26 & 842 & 108.3 & -82.3 \\
Grasses & 37 & 1477 & 190.8 & -153.8 \\
& & & & \\
Total & 2095 & 16268 & & \\
\hline
\end{tabular}

Standard deviation of residuals is $\mathbf{8 9 . 5}$. 


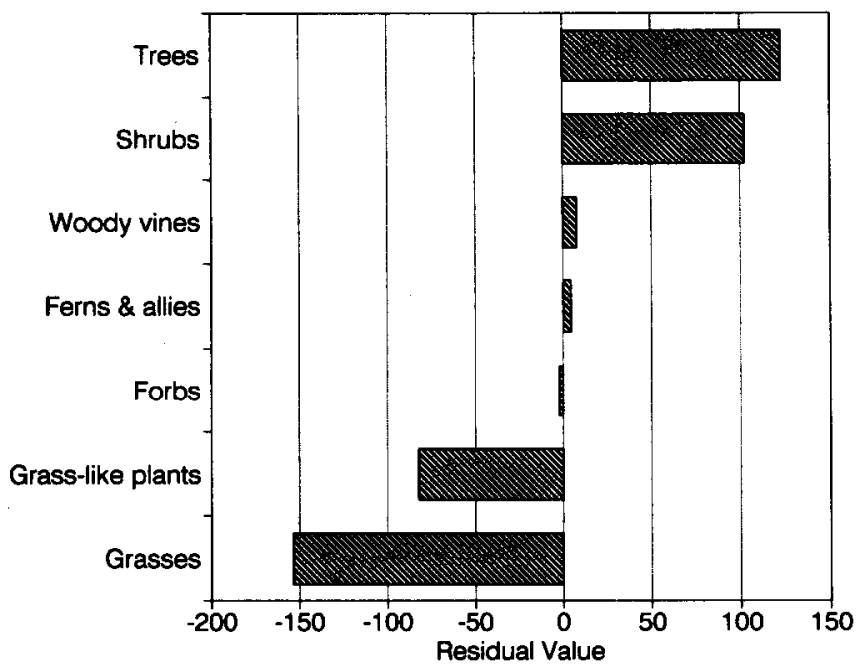

Fig. 3. Regression residuals for seven habit groups. This set of categories is derived from the FNA database which identifies a number of aspects of plant habit, condensed here to seven basic groups. The category "Ferns and allies" comprises six separate small groups from FNA including Fern, Horsetail, Waterfern, Pepperwort, Clubmoss and Quillwort. The category "Shrub" includes the two FNA categories Shrub and Half-shrub. All FNA taxa which had missing or erroneous data were corrected except for two which were excluded from the analysis which is based on 16,268 species.

occur for botanical reasons; they, like grasses, may produce few bioactive chemicals. Or it may occur for ethnological reasons; people reasoning analogically may have assumed that grass-like plants were, like the more common grasses, relatively chemical free. Both situations may be true.

What is most striking is the disproportionate usage of trees and shrubs compared to forbs. The preponderance of trees noted earlier for the Hamamelidae (see Table 6) appears to be much more generally true. It is suggested that the underlying principle accounting for this distribution is the "complexity" of plants. A tree with wood, bark, cambium, branches, leaves, seeds, roots, etc., appears more complex than an herb like plantain or a sunflower. The intermediate position of shrubs and vines seems quite reasonable here. All of those appear more complex in the sense of number of distinct parts than a grass. One may predict that more complex plants, with more parts to defend, would produce more defensive, biologically active chemicals which might be medicinally useful; this should be a testable proposition. Moreover, "trees" are by nature large, hence perceptible, while forbs and grasses might be large, but often are not.

This interpretation is supported by the material displayed in Table 21 . For most taxa in FNA, it is possible to determine a growth pattern; in particular, one can separate annuals from the rest, most of which can be desig- 
TABLE 21

MEDICINAL USAGE OF FNA SPECIES BY LIFE FORM

\begin{tabular}{lrrr}
\hline & Medicinal & Total & $\begin{array}{c}\text { Percent } \\
\text { Medicinal }\end{array}$ \\
\hline All plants & 259 & 3484 & \\
$\quad$ Annuals & 1836 & 12786 & 1.4 \\
Others & & & \\
Commelinidae & 8 & 372 & 2.15 \\
$\quad$ Annuals & 64 & 2059 & 3.1 \\
Others & & & \\
\hline
\end{tabular}

nated perennial or biennial. A comparison of the medicinal and non-medicinal plants in FNA shows that a substantially smaller share of annuals are selected for medicines $(7.4 \%)$ compared to the remainder $(14.4 \%)$. Also shown are the equivalent figures for the Commelinidae where the same pattern is evident; annual grasses and grass-like plants are used medicinally less often than longer-lived taxa.

It seems reasonable to account for this difference in the same way as the differences relating to habit. It is in part redundant since "annual tree" is probably an oxymoron. Biennial or perennial plants are more complex than annual ones; ordinarily they can do all that annuals do and yet they can also survive for more than one year. They are for that reason more likely than annuals to produce bioactive chemicals to protect themselves against predators or competitors. Also perennials must be adapted to long term fluctuations in the incidence of browsing, prepared for the most withering attack. Moreover, perennials are probably easier for people to study and experiment with than annuals. Perennials, by definition, grow year after year in the same place, hence they might be easier to find, examine and analyse.

Of course, many annual forbs are used medicinally. But when one ranks individual species in order of their frequency of use in the MPNA database, one must go to the 41st position on that list before encountering the first annual forb and that is the very unusual species Nicotiana attenuata Torr. Four spaces further down is the next such taxon, Datura meteloides DC. Therefore, while some annual forbs produce more bioactive chemicals than some perennials, typically, it seems that this will not be the case.

\section{Discussion and Conclusions}

These methods are useful in identifying plants used in particularly interesting ways and many species, genera and families have been so identified in this paper. This approach, however, also raises some problems. Earlier, in 
the discussion of $A$ lnus, several contradictory uses of that genus were noted. Other such problems also exist.

Cardiac glycosides act as powerful heart toxins in vertebrates which can also cause severe vomiting, dizziness, blurred vision and diarrhea (Levin, 1976). The best known source of such chemicals is the genus Digitalis. Cardiac glycosides occur in 12 families; one might hypothesize that these families would figure in Native American treatment of their problems with heart and blood. Yet there is not much evidence to indicate that they did so in any significant way.

Table 22 lists the 12 families which produce cardiac glycosides (Seigler, 1981). It also lists the number of genera and species in those families which produce medicines of the cardiology category, which comprises three indications in the database: blood medicine (301 items), heart medicine (94 items) and hypotensive ( 9 items). The twelve families account for $19 \%$ of the genera and $22 \%$ of the species in Flora North America, and 20\% of both the genera and species in the medicinal plants database. Yet only $12 \%$ (49 of 404) of the cardiological treatments come from these families. Those 49 uses are accounted for by 40 different species and 33 different genera; there is very little agreement among the users on which species to select. By contrast, these same 12 families produce $18 \%$ of the emetics in the database (78 of 431 ) and $30 \%$ of the poisons ( 45 of 150 ); they were not generally ignored.

TABLE 22

CARDIOLOGY MEDICINES IN FAMILIES WHICH PRODUCE CARDIAC GLYCOSIDES

\begin{tabular}{llcr}
\hline Family & Genera & Species & Uses \\
\hline Scrophulariaceae & 5 & 6 & 9 \\
Ranunculaceae & 8 & 10 & 10 \\
Apocynaceae & 1 & 2 & 3 \\
Sterculiaceae & 0 & 0 & 0 \\
Celastraceae & 1 & 1 & 1 \\
Tiliaceae & 0 & 0 & 0 \\
Euphorbiaceae & 2 & 2 & 2 \\
Liliaceae & 6 & 8 & 11 \\
Brassicaceae & 3 & 3 & 3 \\
Moraceae & 0 & 0 & 0 \\
Fabaceae & 6 & 7 & 9 \\
Asclepiadaceae & 1 & 1 & 1 \\
Total & & 40 & 49 \\
\hline
\end{tabular}

"Data from Seigler (1981). 
In particular there are no instances in the database of uses of the genus Digitalis. Four species of that genus have been introduced into North America and are reasonably widespread in the northeast, even "locally abundant" in some areas (Fernald, 1970). It was a common matter for Native Americans to use introduced taxa medicinally. Of the 2095 MPNA species, $202(9.6 \%)$ are introduced; this is only a somewhat smaller percentage than the total of introduced plants in the North American flora (2088 of 16270, or 12.8\%). Yet this most useful introduced genus, Digitalis, was not adopted.

What this means is that one cannot imagine uncritically that all Native American usage of medicinal plants meets all possible criteria of "rationality". It surely does not mean that none of the usage is rational. What has been demonstrated here, however, is that there is a kind of order to the collective ethnobotanical wisdom of Native Americans: they emphasized the use of plants which it seems most likely to have produced biologically active secondary products. In an age of limited resources, this suggests that the search for newly useful botanical medicines should concentrate on taxa previously identified as useful by indigenous peoples, rather than on random screening programs.

Using the methods developed here, it would be a straightforward matter to compare the patterns of use in North America with those elsewhere. Such a comparison could lead to interesting information about the nature of the process by which human beings construct knowledge.

But most important, this approach provides a theoretical context with which one may view and make sense of the mass of ethnobotanical data available in North America and elsewhere. It provides a set of techniques by which one may stratify the data in order to select for close analysis taxa which may be more interesting than ones selected at random.

By mechanisms one can only speculate about, Native Americans have accumulated and transmitted an enormous store of accurate and valuable information about the continental flora. We are deeply indebted to them.

\section{Acknowledgments}

This work was supported by the National Science Foundation grant number BNS-8704103. The MPNA database was compiled with financial support from the National Endowment for the Humanities. Stanwyn Shetler supplied the indispensable computerized checklist of species for Flora North America. The University of Michigan-Dearborn provided additional help with funds and a sabbatical leave for research. I wish to extend special thanks to Nina Etkin, Paul Ross, Brent Berlin and Eugene Anderson for reading drafts of the manuscript, to Charlotte Otto for counsel on biochemistry, to Mike Schneider for helpful discussions of plant habit and to Jim Duke for stimulating correspondence about matters ethnobotanical. This paper is dedicated to Keith Irvine. 
REGRESSION ANALYSIS OF 232 NORTH AMERICAN FAMILIES

\begin{tabular}{|c|c|c|c|c|c|}
\hline Rank & Family & Subclass & $\begin{array}{l}\text { FNA } \\
\text { SPE }\end{array}$ & $\begin{array}{l}\text { MPNA } \\
\text { SPE }\end{array}$ & Predicted \\
\hline
\end{tabular}

\begin{tabular}{|c|c|c|c|c|c|c|}
\hline 1 & Asteraceae & Asteridae & 2231 & 345 & 249.9 & 95.1 \\
\hline 2 & Rosaceae & Rosidae & 577 & 115 & 65.5 & 49.5 \\
\hline 3 & Lamiaceae & Asteridae & 320 & 64 & 36.9 & 27.1 \\
\hline 4 & Ranunculaceae & Magnoliidae & 294 & 60 & 34.0 & 26.0 \\
\hline 5 & Pinaceae & Gymnospermae & 71 & 35 & 9.1 & 25.9 \\
\hline 6 & Caprifoliaceae & Asteridae & 77 & 35 & 9.8 & 25.2 \\
\hline 7 & Salicaceae & Dilleniidae & 131 & 40 & 15.8 & 24.2 \\
\hline 8 & Liliaceae & Liliidae & 393 & 67 & 45.0 & 22.0 \\
\hline 9 & Apiaceae & Rosidae & 319 & 58 & 36.8 & 21.2 \\
\hline 10 & Corylaceae & Hamamelidae & 33 & 21 & 4.9 & 16.1 \\
\hline 11 & Saxifragaceae & Rosidae & 260 & 46 & 30.2 & 15.8 \\
\hline 12 & Ericaceae & Dilleniidae & 180 & 36 & 21.3 & 14.7 \\
\hline 13 & Solanaceae & Asteridae & 129 & 28 & 15.6 & 12.4 \\
\hline 14 & Cupressaceae & Gymnospermae & 27 & 15 & 4.2 & 10.8 \\
\hline 15 & Fagaceae & Hamamelidae & 140 & 26 & 16.8 & 9.2 \\
\hline 16 & Cornaceae & Rosidae & 17 & 12 & 3.1 & 8.9 \\
\hline 17 & Polypodiaceae & Pteridophyta & 215 & 33 & 25.2 & 7.8 \\
\hline 18 & Pyrolaceae & Dilleniidae & 27 & 12 & 4.2 & 7.8 \\
\hline 19 & Berberidaceae & Magnoliidae & 29 & 12 & 4.5 & 7.5 \\
\hline 20 & Aceraceae & Rosidae & 15 & 10 & 2.9 & 7.1 \\
\hline 21 & Polygonaceae & Caryophyllidae & 413 & 54 & 47.3 & 6.8 \\
\hline 22 & Asclepiadaceae & Asteridae & 97 & 18 & 12.0 & 6.0 \\
\hline 23 & Araliaceae & Rosidae & 10 & 8 & 2.3 & 5.7 \\
\hline 24 & Araceae & Arecidae & 16 & 8 & 3.0 & 5.0 \\
\hline 25 & Juglandaceae & Hamamelidae & 25 & 9 & 4.0 & 5.0 \\
\hline 26 & Rhamnaceae & Rosidae & 80 & 15 & 10.1 & 4.9 \\
\hline 27 & Anacardiaceae & Rosidae & 27 & 9 & 4.2 & 4.8 \\
\hline 28 & Cucurbitaceae & Dilleniidae & 47 & 11 & 6.5 & 4.5 \\
\hline 29 & Nyctaginaceae & Caryophyllidae & 103 & 17 & 12.7 & 4.3 \\
\hline 30 & Equisetaceae & Pteridophyta & 16 & 7 & 3.0 & 4.0 \\
\hline 31 & Loranthaceae & Rosidae & 16 & 7 & 3.0 & 4.0 \\
\hline 32 & Urticaceae & Hamamelidae & 17 & 7 & 3.1 & 3.9 \\
\hline 33 & Plantaginaceae & Asteridae & 28 & 8 & 4.3 & 3.7 \\
\hline 34 & Violaceae & Dilleniidae & 84 & 14 & 10.6 & 3.4 \\
\hline 35 & Oleaceae & Asteridae & 50 & 10 & 6.8 & 3.2 \\
\hline 36 & Gentianaceae & Asteridae & 89 & 14 & 11.1 & 2.9 \\
\hline 37 & Ephedraceae & Gymnospermae & 9 & 5 & 2.2 & 2.8 \\
\hline 38 & Magnoliaceae & Magnoliidae & 9 & 5 & 2.2 & 2.8 \\
\hline 39 & Iridaceae & Liliidae & 81 & 13 & 10.2 & 2.8 \\
\hline 40 & Celastraceae & Rosidae & 28 & 7 & 4.3 & 2.7 \\
\hline 41 & Aristolochiaceae & Magnoliidae & 20 & 6 & 3.4 & 2.6 \\
\hline 42 & Valerianaceae & Asteridae & 30 & 7 & 4.6 & 2.4 \\
\hline 43 & Santalaceae & Rosidae & 5 & 4 & 1.8 & 2.2 \\
\hline 44 & Clusiaceae & Dilleniidae & 50 & 9 & 6.8 & 2.2 \\
\hline 45 & Geraniaceae & Rosidae & 51 & 9 & 6.9 & 2.1 \\
\hline
\end{tabular}


APPENDIX A (Continued)

\begin{tabular}{|c|c|c|c|c|c|c|}
\hline Rank & Family & Subclass & $\begin{array}{l}\text { FNA } \\
\text { SPE }\end{array}$ & $\begin{array}{l}\text { MPNA } \\
\text { SPE }\end{array}$ & Predicted & Residual \\
\hline
\end{tabular}

\begin{tabular}{|c|c|c|c|c|c|c|}
\hline 46 & Oxalidaceae & Rosidae & 25 & 6 & 4.0 & 2.0 \\
\hline 47 & Vitaceae & Rosidae & 34 & 7 & 5.0 & 2.0 \\
\hline 48 & Lycopodiaceae & Pteridophyta & 17 & 5 & 3.1 & 1.9 \\
\hline 49 & Hippocastanaceae & Rosidae & 9 & 4 & 2.2 & 1.8 \\
\hline 50 & Ulmaceae & Hamamelidae & 18 & 5 & 3.2 & 1.8 \\
\hline 51 & Moraceae & Hamamelidae & 19 & 5 & 3.3 & 1.7 \\
\hline 52 & Rutaceae & Rosidae & 37 & 7 & 5.3 & 1.7 \\
\hline 53 & Osmundaceae & Pteridophyta & 3 & 3 & 1.6 & 1.4 \\
\hline 54 & Calycanthaceae & Magnoliidae & 3 & 3 & 1.6 & 1.4 \\
\hline 55 & Lauraceae & Magnoliidae & 12 & 4 & 2.5 & 1.4 \\
\hline 56 & Taxaceae & Gymnospermae & 5 & 3 & 1.8 & 1.2 \\
\hline 57 & Nymphaeaceae & Magnoliidae & 16 & 4 & 3.0 & 1.0 \\
\hline 58 & Myricaceae & Hamamelidae & 8 & 3 & 2.1 & 0.9 \\
\hline 59 & Elaeagnaceae & Rosidae & 8 & 3 & 2.1 & 0.9 \\
\hline 60 & Apocynaceae & Asteridae & 35 & 6 & 5.1 & 0.9 \\
\hline 61 & Aquifoliaceae & Rosidae & 17 & 4 & 3.1 & 0.9 \\
\hline 62 & Papaveraceae & Magnoliidae & 89 & 12 & 11.1 & 0.9 \\
\hline 63 & Orobanchaceae & Asteridae & 18 & 4 & 3.2 & 0.8 \\
\hline 64 & Verbenaceae & Asteridae & 90 & 12 & 11.2 & 0.8 \\
\hline 65 & Orchidaceae & Liliidae & 171 & 21 & 20.3 & 0.7 \\
\hline 66 & Zygophyllaceae & Rosidae & 19 & 4 & 3.3 & 0.7 \\
\hline 67 & Saururaceae & Magnoliidae & 2 & 2 & 1.4 & 0.6 \\
\hline 68 & Platanaceae & Hamamelidae & 4 & 2 & 1.7 & 0.3 \\
\hline 69 & Hamamelidaceae & Hamamelidae & 4 & 2 & 1.7 & 0.3 \\
\hline 70 & Typhaceae & Commelinidae & 4 & 2 & 1.7 & 0.3 \\
\hline 71 & Martyniaceae & Asteridae & 5 & 2 & 1.8 & 0.2 \\
\hline 72 & Menispermaceae & Magnoliidae & 5 & 2 & 1.8 & 0.2 \\
\hline 73 & Thymelaeaceae & Rosidae & 5 & 2 & 1.8 & 0.2 \\
\hline 74 & Alismataceae & Alismatidae & 24 & 4 & 3.9 & 0.1 \\
\hline 75 & Chenopodiaceae & Caryophyllidae & 151 & 18 & 18.0 & 0.0 \\
\hline 76 & Pontederiaceae & Lilidae & 9 & 2 & 2.2 & -0.2 \\
\hline 77 & Loganiaceae & Asteridae & 9 & 2 & 2.2 & -0.2 \\
\hline 78 & Datiscaceae & Dilleniidae & 1 & 1 & 1.3 & -0.3 \\
\hline 79 & Phrymaceae & Asteridae & 1 & 1 & 1.3 & -0.3 \\
\hline 80 & Fouquieriaceae & Dilleniidae & 1 & 1 & 1.3 & -0.3 \\
\hline 81 & Symplocaceae & Dilleniidae & 1 & 1 & 1.3 & -0.3 \\
\hline 82 & Ebenaceae & Dilleniidae & 2 & 1 & 1.4 & -0.4 \\
\hline 83 & Buxaceae & Rosidae & 2 & 1 & 1.4 & -0.4 \\
\hline 84 & Paeoniaceae & Dilleniidae & 2 & 1 & 1.4 & -0.4 \\
\hline 85 & Balsaminaceae & Rosidae & 11 & 2 & 2.4 & -0.4 \\
\hline 86 & Staphyleaceae & Rosidae & 2 & 1 & 1.4 & -0.4 \\
\hline 87 & Clethraceae & Dilleniidae & 2 & 1 & 1.4 & -0.4 \\
\hline 88 & Polygalaceae & Rosidae & 47 & 6 & 6.5 & -0.5 \\
\hline 89 & Meliaceae & Rosidae & 3 & 1 & 1.6 & -0.6 \\
\hline 90 & Polemoniaceae & Asteridae & 237 & 27 & 27.6 & -0.6 \\
\hline 91 & Diapensiaceae & Dilleniidae & 4 & 1 & 1.7 & -0.7 \\
\hline 92 & Nyssaceae & Rosidae & 4 & 1 & 1.7 & -0.7 \\
\hline
\end{tabular}


APPENDIX A (Continued)

\begin{tabular}{|c|c|c|c|c|c|c|}
\hline Rank & Family & Subclass & $\begin{array}{l}\text { FNA } \\
\text { SPE }\end{array}$ & $\begin{array}{l}\text { MPNA } \\
\text { SPE }\end{array}$ & Predicted & Residual \\
\hline
\end{tabular}

\begin{tabular}{|c|c|c|c|c|c|c|}
\hline 93 & Haemodoraceae & Liliidae & 4 & 1 & 1.7 & -0.7 \\
\hline 94 & Tiliaceae & Dilleniidae & 13 & 2 & 2.7 & -0.7 \\
\hline 95 & Dioscoreaceae & Liliidae & 5 & 1 & 1.8 & -0.8 \\
\hline 96 & Taxodiaceae & Gymnospermae & 5 & 1 & 1.8 & -0.8 \\
\hline 97 & Empetraceae & Dilleniidae & 6 & 1 & 1.9 & -0.9 \\
\hline 98 & Phytolaccaceae & Caryophyllidae & 6 & 1 & 1.9 & -0.9 \\
\hline 99 & Lythraceae & Rosidae & 25 & 3 & 4.0 & -1.0 \\
\hline 100 & Linaceae & Rosidae & 35 & 4 & 5.1 & -1.1 \\
\hline 101 & Plumbaginaceae & Caryophyllidae & 9 & 1 & 2.2 & -1.2 \\
\hline 102 & Sarraceniaceae & Dilleniidae & 9 & 1 & 2.2 & -1.2 \\
\hline 103 & Melastomataceae & Rosidae & 10 & 1 & 2.3 & -1.3 \\
\hline 104 & Cycadaceae & Gymnospermae & 1 & 0 & 1.3 & -1.3 \\
\hline 105 & Moringaceae & Dilleniidae & 1 & 0 & 1.3 & -1.3 \\
\hline 106 & Musaceae & Commelinidae & 1 & 0 & 1.3 & -1.3 \\
\hline 107 & Adoxaceae & Asteridae & 1 & 0 & 1.3 & -1.3 \\
\hline 108 & Myoporaceae & Asteridae & 1 & 0 & 1.3 & -1.3 \\
\hline 109 & Dipsacaceae & Asteridae & 10 & 1 & 2.3 & -1.3 \\
\hline 110 & Droseraceae & Dilleniidae & 10 & 1 & 2.3 & -1.3 \\
\hline 111 & Elaeocarpaceae & Dilleniidae & 1 & 0 & 1.3 & -1.3 \\
\hline 112 & Parkeriaceae & Pteridophyta & 1 & 0 & 1.3 & -1.3 \\
\hline 113 & Pilulariaceae & Pteridophyta & 1 & 0 & 1.3 & -1.3 \\
\hline 114 & Schisandraceae & Magnoliidae & 1 & 0 & 1.3 & -1.3 \\
\hline 115 & Podostemaceae & Rosidae & 1 & 0 & 1.3 & -1.3 \\
\hline 116 & Leitneriaceae & Hamamelidae & 1 & 0 & 1.3 & -1.3 \\
\hline 117 & Trapaceae & Rosidae & 1 & 0 & 1.3 & -1.3 \\
\hline 118 & Proteaceae & Rosidae & 1 & 0 & 1.3 & -1.3 \\
\hline 119 & Punicaceae & Rosidae & 1 & 0 & 1.3 & -1.3 \\
\hline 120 & Garryaceae & Rosidae & 10 & 1 & 2.3 & -1.3 \\
\hline 121 & Rafflesiaceae & Rosidae & 1 & 0 & 1.3 & -1.3 \\
\hline 122 & Rhizophoraceae & Rosidae & 1 & 0 & 1.3 & -1.3 \\
\hline 123 & Goodeniaceae & Asteridae & 1 & 0 & 1.3 & -1.3 \\
\hline 124 & Salviniaceae & Pteridophyta & 1 & 0 & 1.3 & -1.3 \\
\hline 125 & Caricaceae & Dilleniidae & 1 & 0 & 1.3 & -1.3 \\
\hline 126 & Hippocrateaceae & Rosidae & 1 & 0 & 1.3 & -1.3 \\
\hline 127 & Achatocarpaceae & Caryophyllidae & 1 & 0 & 1.3 & -1.3 \\
\hline 128 & Scheuchzeriaceae & Alismatidae & 1 & 0 & 1.3 & -1.3 \\
\hline 129 & Bataceae & Caryophyllidae & 1 & 0 & 1.3 & -1.3 \\
\hline 130 & Sphenocleaceae & Asteridae & 1 & 0 & 1.3 & -1.3 \\
\hline 131 & Stemonaceae & Liliidae & 1 & 0 & 1.3 & -1.3 \\
\hline 132 & Begoniaceae & Dilleniidae & 1 & 0 & 1.3 & -1.3 \\
\hline 133 & Theophrastaceae & Dilleniidae & 1 & 0 & 1.3 & -1.3 \\
\hline 134 & Tropaeolaceae & Rosidae & 1 & 0 & 1.3 & -1.3 \\
\hline 135 & Zingiberaceae & Commelinidae & 1 & 0 & 1.3 & -1.3 \\
\hline 136 & Aponogetonaceae & Alismatidae & 1 & 0 & 1.3 & -1.3 \\
\hline 137 & Bixaceae & Dilleniidae & 1 & 0 & 1.3 & -1.3 \\
\hline 138 & Calyceraceae & Asteridae & 1 & 0 & 1.3 & -1.3 \\
\hline 139 & Mayacaceae & Commelinidae & 2 & 0 & 1.4 & -1.4 \\
\hline
\end{tabular}


APPENDIX A (Continued)

\begin{tabular}{|c|c|c|c|c|c|c|}
\hline Rank & Family & Subclass & $\begin{array}{l}\text { FNA } \\
\text { SPE }\end{array}$ & $\begin{array}{l}\text { MPNA } \\
\text { SPE }\end{array}$ & Predicted & Residual \\
\hline
\end{tabular}

\begin{tabular}{|c|c|c|c|c|c|c|}
\hline 140 & Butomaceae & Alismatidae & 2 & 0 & 1.4 & -1.4 \\
\hline 141 & Lennoaceae & Asteridae & 2 & 0 & 1.4 & -1.4 \\
\hline 142 & Pedaliaceae & Asteridae & 2 & 0 & 1.4 & -1.4 \\
\hline 143 & Canellaceae & Magnoliidae & 2 & 0 & 1.4 & -1.4 \\
\hline 144 & Ceratophyllaceae & Magnoliidae & 2 & 0 & 1.4 & -1.4 \\
\hline 145 & Chrysobalanaceae & Rosidae & 2 & 0 & 1.4 & -1.4 \\
\hline 146 & Illiciaceae & Magnoliidae & 2 & 0 & 1.4 & -1.4 \\
\hline 147 & Limnanthaceae & Rosidae & 2 & 0 & 1.4 & -1.4 \\
\hline 148 & Flacourtiaceae & Dilleniidae & 2 & 0 & 1.4 & -1.4 \\
\hline 149 & Marantaceae & Commelinidae & 3 & 0 & 1.6 & -1.6 \\
\hline 150 & Crossosomataceae & Dilleniidae & 3 & 0 & 1.6 & -1.6 \\
\hline 151 & Azollaceae & Pteridophyta & 3 & 0 & 1.6 & -1.6 \\
\hline 152 & Burseraceae & Rosidae & 3 & 0 & 1.6 & -1.6 \\
\hline 153 & Basellaceae & Caryophyllidae & 3 & 0 & 1.6 & -1.6 \\
\hline 154 & Cannaceae & Commelinidae & 3 & 0 & 1.6 & -1.6 \\
\hline 155 & Sparganiaceae & Commelinidae & 12 & 1 & 2.5 & -1.6 \\
\hline 156 & Frankeniaceae & Dilleniidae & 3 & 0 & 1.6 & -1.6 \\
\hline 157 & Casuarinaceae & Hamamelidae & 3 & 0 & 1.6 & -1.6 \\
\hline 158 & Hippuridaceae & Rosidae & 3 & 0 & 1.6 & -1.6 \\
\hline 159 & Cochlospermaceae & Dilleniidae & 3 & 0 & 1.6 & -1.6 \\
\hline 160 & Olacaceae & Rosidae & 3 & 0 & 1.6 & $-\mathbf{1 . 6}$ \\
\hline 161 & Turneraceae & Dilleniidae & 3 & 0 & 1.6 & -1.6 \\
\hline 162 & Menyanthaceae & Asteridae & 4 & 0 & 1.7 & -1.7 \\
\hline 163 & Myrsinaceae & Dilleniidae & 4 & 0 & 1.7 & -1.7 \\
\hline 164 & Theaceae & Dilleniidae & 4 & 0 & 1.7 & -1.7 \\
\hline 165 & Zannichelliaceae & Alismatidae & 4 & 0 & 1.7 & -1.7 \\
\hline 166 & Cyrillaceae & Dilleniidae & 4 & 0 & 1.7 & -1.7 \\
\hline 167 & Commelinaceae & Commelinidae & 40 & 4 & 5.7 & -1.7 \\
\hline 168 & Tamaricaceae & Dilleniidae & 5 & 0 & 1.8 & -1.8 \\
\hline 169 & Resedaceae & Dilleniidae & 5 & 0 & 1.8 & -1.8 \\
\hline 170 & Molluginaceae & Caryophyllidae & 5 & 0 & 1.8 & -1.8 \\
\hline 171 & Burmanniaceae & Liliidae & 5 & 0 & 1.8 & -1.8 \\
\hline 172 & Krameriaceae & Rosidae & 5 & 0 & 1.8 & -1.8 \\
\hline 173 & Combretaceae & Rosidae & 5 & 0 & 1.8 & -1.8 \\
\hline 174 & Juncaginaceae & Alismatidae & 5 & 0 & 1.8 & -1.8 \\
\hline 175 & Bignoniaceae & Asteridae & 14 & 1 & 2.8 & -1.8 \\
\hline 176 & Schizaeaceae & Pteridophyta & 5 & 0 & 1.8 & -1.8 \\
\hline 177 & Piperaceae & Magnoliidae & 6 & 0 & 1.9 & -1.9 \\
\hline 178 & Marsileaceae & Pteridophyta & 6 & 0 & 1.9 & -1.9 \\
\hline 179 & Passifloraceae & Dilleniidae & 15 & 1 & 2.9 & -1.9 \\
\hline 180 & Haloragaceae & Rosidae & 15 & 1 & 2.9 & -1.9 \\
\hline 181 & Najadaceae & Alismatidae & 7 & 0 & 2.0 & -2.0 \\
\hline 182 & Hymenophyllaceae & Pteridophyta & 7 & 0 & 2.0 & -2.0 \\
\hline 183 & Simaroubaceae & Rosidae & 7 & 0 & 2.0 & -2.0 \\
\hline 184 & Primulaceae & Dilleniidae & 79 & 8 & 10.0 & -2.0 \\
\hline 185 & Xyridaceae & Commelinidae & 17 & 1 & 3.1 & -2.1 \\
\hline 186 & Buddlejaceae & Asteridae & 8 & 0 & 2.1 & -2.1 \\
\hline
\end{tabular}


APPENDIX A (Continued)

\begin{tabular}{|c|c|c|c|c|c|c|}
\hline Rank & Family & Subclass & $\begin{array}{l}\text { FNA } \\
\text { SPE }\end{array}$ & $\begin{array}{l}\text { MPNA } \\
\text { SPE }\end{array}$ & Predicted & Residual \\
\hline 187 & Styracaceae & Dilleniidae & 8 & 0 & 2.1 & -2.1 \\
\hline 188 & Sterculiaceae & Dilleniidae & 17 & 1 & 3.1 & -2.1 \\
\hline 189 & Hypoxidaceae & Liliidae & 8 & 0 & 2.1 & -2.1 \\
\hline 190 & Ophioglossaceae & Pteridophyta & 18 & 1 & 3.2 & -2.2 \\
\hline 191 & Sapindaceae & Rosidae & 18 & 1 & 3.2 & -2.2 \\
\hline 192 & Elatinaceae & Dilleniidae & 9 & 0 & 2.2 & -2.2 \\
\hline 193 & Eriocaulaceae & Commelinidae & 10 & 0 & 2.3 & -2.3 \\
\hline 194 & Malpighiaceae & Rosidae & 10 & 0 & 2.3 & -2.3 \\
\hline 195 & Rubiaceae & Asteridae & 145 & 15 & 17.4 & -2.4 \\
\hline 196 & Bromeliaceae & Commelinidae & 20 & 1 & 3.4 & -2.4 \\
\hline 197 & Campanulaceae & Asteridae & 110 & 11 & 13.5 & -2.5 \\
\hline 198 & Callitrichaceae & Asteridae & 12 & 0 & 2.5 & -2.5 \\
\hline 199 & Capparidaceae & Dilleniidae & 30 & 2 & 4.6 & -2.6 \\
\hline 200 & Cistaceae & Dilleniidae & 31 & 2 & 4.7 & -2.7 \\
\hline 201 & Hydrocharitaceae & Alismatidae & 14 & 0 & 2.8 & -2.8 \\
\hline 202 & Lemnaceae & Arecidae & 14 & 0 & 2.8 & -2.8 \\
\hline 203 & Annonaceae & Magnoliidae & 15 & 0 & 2.9 & -2.9 \\
\hline 204 & Loasaceae & Dilleniidae & 51 & 4 & 6.9 & -2.9 \\
\hline 205 & Sapotaceae & Dilleniidae & 16 & 0 & 3.0 & -3.0 \\
\hline 206 & Aizoaceae & Caryophyllidae & 17 & 0 & 3.1 & -3.1 \\
\hline 207 & Arecaceae & Arecidae & 17 & 0 & 3.1 & -3.1 \\
\hline 208 & Isoetaceae & Pteridophyta & 17 & 0 & 3.1 & -3.1 \\
\hline 209 & Amaryllidaceae & Liliidae & 37 & 2 & 5.3 & -3.3 \\
\hline 210 & Lentibulariaceae & Asteridae & 21 & 0 & 3.5 & -3.5 \\
\hline 211 & Crassulaceae & Rosidae & 85 & 7 & 10.7 & -3.7 \\
\hline 212 & Portulacaceae & Caryophyllidae & 85 & 7 & 10.7 & -3.7 \\
\hline 213 & Convolvulaceae & Asteridae & 125 & 11 & 15.2 & -4.2 \\
\hline 214 & Myrtaceae & Rosidae & 27 & 0 & 4.2 & -4.2 \\
\hline 215 & Zosteraceae & Alismatidae & 46 & 2 & 6.3 & -4.3 \\
\hline 216 & Selaginellaceae & Pteridophyta & 30 & 0 & 4.6 & -4.6 \\
\hline 217 & Amaranthaceae & Caryophyllidae & 74 & 4 & 9.5 & -5.5 \\
\hline 218 & Onagraceae & Rosidae & 247 & 23 & 28.7 & -5.7 \\
\hline 219 & Malvaceae & Dilleniidae & 213 & 19 & 24.9 & -6.0 \\
\hline 220 & Brassicaceae & Dilleniidae & 510 & 52 & 58.1 & -6.1 \\
\hline 221 & Cactaceae & Caryophyllidae & 180 & 14 & 21.3 & -7.3 \\
\hline 222 & Euphorbiaceae & Rosidae & 264 & 23 & 30.6 & -7.6 \\
\hline 223 & Acanthaceae & Asteridae & 65 & 0 & 8.5 & -8.5 \\
\hline 224 & Scrophulariaceae & Asteridae & 632 & 63 & 71.7 & -8.7 \\
\hline 225 & Hydrophyllaceae & Asteridae & 183 & 12 & 21.6 & -9.6 \\
\hline 226 & Boraginaceae & Asteridae & 304 & 25 & 35.1 & -10.1 \\
\hline 227 & Agavaceae & Liliidae & 86 & 0 & 10.8 & -10.8 \\
\hline 228 & Juncaceae & Commelinidae & 123 & 4 & 14.9 & -10.9 \\
\hline 229 & Caryophyllaceae & Caryophyllidae & 287 & 22 & 33.2 & -11.2 \\
\hline 230 & Fabaccae & Rosidae & 1225 & 108 & 137.8 & -29.8 \\
\hline 231 & Cyperaceae & Commelinidae & 718 & 22 & 81.2 & -59.2 \\
\hline 232 & Poaceae & Commelinidae & 1477 & 37 & 165.8 & -128.8 \\
\hline Total & & & 16270 & 2095 & & \\
\hline
\end{tabular}




\section{APPENDIX B}

INDICATIONS AND THERAPEUTIC CATEGORIES

Cardiology (CAR)

Dermatology (DER)

General (GEN)

Gastro-Intestinal (GIM)

Gynecological-urinary

(GYN)

Neurological (NEU)

Orthopedic (ORT)
Blood medicine

Heart medicine

94

Hypotensive

Burn dressing

Dermatological aid

Hemostat

1762

121

Adjuvant

Alterative

Panacea

Anthelmintic $\quad 139$

Antidiarrheal $\quad \mathbf{4 1 4}$

Antiemetic $\quad 83$

Antihemorrhagic $\quad 91$

Carminative 49

Cathartic $\quad 249$

Diaphoretic $\quad 144$

Dietary aid $\quad 98$

Emetic 431

Gast.-Intestinal aid $\quad 838$

Hemorrhoid remedy 56

Laxative $\quad 165$

Liver aid $\quad 91$

Abortifacient $\quad 104$

Breast treatment $\quad 17$

Contraceptive $\quad 26$

Diuretic 128

Gynecological aid $\quad \mathbf{6 6 6}$

Kidney aid 253

Reproductive aid $\quad 15$

Urinary aid 209

Venereal aid 343

Analgesic $\quad 938$

Anesthetic 4

Anticonvulsive $\quad 68$

Febrifuge $\quad 406$

Hallucinogen 12

Narcotic $\quad 22$

Sedative $\quad 110$

Stimulant $\quad 214$

Antirheumatic - Ext. $\quad 239$

Antirheumatic - Int. $\quad 166$

Orthopedic aid 351 
Other (OTH)

Antidote $\quad 51$

Cancer treatment 29

Ceremonial medicine $\quad 338$

Disinfectant 191

Herbal steam $\quad 73$

Hunting medicine $\quad \mathbf{5 5}$

Insecticide 44

Love medicine $\quad 87$

Misc disease remedy $\quad 326$

Other 485

Pediatric aid $\quad 455$

Poison $\quad 150$

Psychological aid $\quad 70$

Snake bite remedy $\quad 142$

Strengthener 24

Tonic 331

Tuberculosis remedy $\quad 257$

Unspecified 196

Veterinary aid 234

Witcheraft medicine $\quad 141$

$\begin{array}{lll}\text { Oto-rhino-laryngological (OTO) } & \text { Ear medicine } & \mathbf{7 0}\end{array}$

Eye medicine $\quad 346$

Nose medicine $\quad 17$

Oral aid 143

Throat aid 254

Toothache remedy 184

$\begin{array}{lll}\text { Pulmonary (PUL) } & \text { Cold remedy } & 528\end{array}$

Cough medicine $\quad 356$

Expectorant 32

Pulmonary aid $\quad 257$

Respiratory aid $\quad 173$

\section{References}

Ayensu, E.S. (1978) Medicinal Plants of West Africa. Reference Publications, Algonac, Michigan, p. 153.

Bell, E.A. (1981) The physiological role(s) of secondary (natural) products. In: E.E. Conn (Ed.), Secondary Plant Products, Volume 7 of P.K. Stumpf and E.E. Conn (Eds.), The Biochemistry of Plants: A Comprehensive Treatise. Academic Press, New York, p. 11.

Berkow, R. (1987) The Merck Manual of Diagnosis and Therapy. Merck Sharp and Dohme Research Laboratories, Rahway, New Jersey.

Berlin, B., Breedlove, D.E. and Raven, P.H. (1973) General principles of classification and nomenclature in folk biology. American Anthropologist 75, 214-222.

Brower, L.P., Nelson, C.J., Seiber, J.N., Fink, L.S. and Bond, C. (1988) Exaptation as an alternative to coevolution in the cardenolide-based chemical defense of monarch butterflies Danaus 
plexippus L.) against avian predators. In: K.C. Spencer (Ed.), Chemical Mediation of Coevolution Academic Press, San Diego, California, pp. 447-476.

Bushnell, D.1. Jr. (1909) The Choctaw of Bayou Lacomb, St. Tammany Parish, Louistana. Bureau of American Ethnology Bulletin No. 48. Smithsonian Institution, Washington, D.C., p. 23.

Chapman, R.F. and Blaney, W.M. (1979) How animals perceive secondary compounds. In: G.A. Rosenthal and D.H. Janzen (Eds.), Herbivores: Their Interaction with Secondary Plant Metabolites. Academic Press, New York, pp. 189-190.

Claus, E.P., Tyler, V.E. and Brady, L.R. (1970) Pharmacognosy. 6th Edn. Lea and Febiger, Philadelphia, pp. 113-114, 179, 185, 199-200, 229.

Conn, E.E. (1979) Cyanide and cyanogenie glycosides. In: G.A. Rosenthal and D.H. Janzen (Eds.), Herbivores: Their Interaction with Secondary Plant Metabolites. Academic Press, New York, p. 394.

Cronquist, A. (1968) The Evolution and Classification of Flowering Plants. Houghton Mifflin, Boston, 396 pp.

Csordas, T.A. (1989) The sore that does not heal: cause and concept in the Navajo experience of cancer. Journal of Anthropological Research 45(4), 457-485.

Dahlgren, R.M.T., Clifford, H.T. and Yeo, P.F. (1985) The Families of the Monocotyledons: Structure, Evolution, and Taxonomy. Springer-Verlag, Berlin, p. 20.

Dahlgren, R.M.T., Rosendal-Jensen, S. and Nielsen, B.J. (1982) A revised classification of the angiosperms with comments on the correlation between chemical and other characteristics. In: D.A. Young and D.S. Seigler (Eds.), Phytochemistry and Angiosperm Phylogeny. Praeger, New York, pp. 149-204.

Davidek, J., Pudil, F., Velisek, J. and Kubelka, V. (1981) Volatile constituents of elder (Sambucus nigra): 2. Berries. Lebensmittel Wessenschaft und Technologie 14, 181-182.

De Villez, R.L. (1985) Topical minoxidil therapy in hereditary androgenetic alopecia. Archives of Dermatology 121, 197-202.

De Villez, R.L. (1988) Androgenetic alopecia: from empiricism to knowledge. Clinics in Dermatology $6(4), 1-235$.

Duke, J. and Ayensu, E. (1985) Medicinal Plants of China. Reference Publications, Algonac, Michigan, p. 236.

Dunn, C.J., Koh, M.S., Willoughby, D.A. and Giroud, J.P. (1977) The value of multifactorial screening for anti-inflammatory activity as shown by coumarin. Journal of Pathology 122, 201 $-207$.

Farnsworth, N.R., Bingel, A.S., Cordell, G.A., Crane, F.A. and Fong, H.H.S. (1975) Potential value of plants as sources of new antifertility agents. Joumal of Phamaceutical Sciences 64, $535-598,717-754$.

Fenton, W.N. (1941) Iroquois Suicide: A Study in the Stability of a Culture Pattern Anthropological Papers, No. 14, Bureau of American Ethnology Bulletin 128, 80-137. Smithsonian Institution, Washington, D.C., p. 455.

Fenton, W.N. (1986) A further note on Iroquois suicide. Ethnohistory 33, 448-457.

Fernald, M.L. (1970) Gray's Manual of Botany. 8th Edn., corrected printing. D. Van Nostrand, New York, pp. xvi, 1279-1280.

Gilman, A., Goodman, L.S. and Gilman, A. (Eds.) (1980) Goodman and Gilman's The Pharmacological Basis of Therapeutics. 6th Edn. Macmillan, New York, pp. 682-698.

Goodman, L.S. and Gilman, A. (Eds.) (1970) The Pharmacological Basis of Therapeutics. 4th Edn. Macmillan, New York, pp. 339-341, 519, 1633.

Gould, F. (1988) Genetics of pairwise and multispecies plant-herbivore coevolution. In: K.C. Spencer (Ed.), Chemical Mediation of Coevolution. Academic Press, San Diego, California, pp. 1356.

Gupta, M.B., Nath, R., Srivastava, M., Shanker, K., Kishor, K. and Bhargava, K.P. (1980) Antiinflammatory and antipyretic activities of beta-sitosterol. Planta Medica 39, 157-63.

Hargreaves, R.T., Johnson, R.D., Millington, D.S., Mondal, M.H., Beavers, W., Becker, L., Young, C. and Rinehart, K.R. Jr. (1974) Alkaloids of the American species of Erythrina Lloydia 37, $569-580$. 
Harner, M. (1973) The role of hallucinogenic plants in European witcheraft. In: Michael Harner (Ed.), Hallucinogens and Shamanism. Oxford University Press, New York, pp. 125-150.

Hartwell, J.L. (1982) Plants Used against Cancer: A Survey. Quarterman Publications, Lawrence, Massachusetts, pp. 60, 93-94.

Jensen, S.R. and Nielsen, B.J. (1973) Cyanogenic glycosides in Sambucus nigra L. Acta Chemica Scandia 27, 2661-2662.

Lee, R.E., Bykadi, B. and Ritschel, W.A. (1981) Inhibition of prostaglandin biosynthesis by coumarin, 4-hydroxycoumarin and 7-hydroxycoumarin. Arzneimittel-Forchung Drug Research $31,640-642$.

Levin, D.A. (1976) The chemical defenses of plants to pathogens and herbivores. Annual Review of Ecological Systems 7, 121-59.

Lewis, W.H. and Elvin-Lewis, M. (1977) Medical Botany: Plants Affecting Man's Health. John Wiley, New York, pp. 19, 21, 151.

Lin, C.-N. and Tome, W.-P. (1988) Antihepatotoxic principles of Sambucus formosana. Planta Medica 54, 223-224.

Lindroth, R.L. (1988) Adaptations of mammalian herbivores to plant chemical defenses. In: K.C. Spencer (Ed.), Chemical Mediation of Coevolution. Academic Press, San Diego, pp. 415-446.

Lombard, L. (1952) Medicinal plants of our Maine Indians. In: Maine Writers Research Club, Maine Indians in History and Legends. Severn, Wylie, Jewett Company, Portland, ME, pp. 96-102.

Merrill, W.L. (1977) An Investigation of Ethnographic and Archaeological Specimens of Mescalbeans (Sophora secundifloral in American Museums. Technical Reports, No. 6. University of Michigan Museum of Anthropology, Ann Arbor, pp. 27-42.

Moerman, D.E. (1974) Extended Family and Popular Medicine on St. Helena Island, S.C.: Adaptations to Marginality. University Microfilms, Ann Arbor, 290 pp.

Moerman, D.E. (1977) American Medical Ethnobotany: A Reference Dictionary. Garland Publishing Co., New York, 527 pp.

Moerman, D.E. (1979) Symbols and selectivity: a statistical analysis of Native American medical ethnobotany. Journal of Ethnopharmacology 1, 111-119.

Moerman, D.E. (1986) Medicinal Plants of Native America. Technical Reports, No. 19. Two volumes. University of Michigan Museum of Anthropology, Ann Arbor, $910 \mathrm{pp}$.

Moerman, D.E. (1989) Poisoned apples and honeysuckles: the medicinal plants of Native America. Medical Anthropology Quarterly 3, 52-61.

Mumcuoglu, M., Manor, D. and Slavin, S. (1986) Enrichment for GM-CFU from human bone marrow using Sambucus nigra agglutinin: potential applications to bone marrow transplantation. Experimental Hematology 14, 946-950.

Osol, A. and Pratt, R. (1973) The United States Dispensatory. Lippincott, Philadelphia, p. 697.

Raichelson, R.M. (1986) Coumarin-containing plants and serum albumin polymorphisms: biomedical implications for Native Americans of the southwest. In: Nina Etkin (Ed.), Plants in Indigenous Medicine and Diet: Biobehavioral Approaches. Redgrave, Bedford Hills, New York, pp. $229-251$.

Renwick, J.A.A. (1988) Comparative mechanisms of host selection by insects attacking pine trees and crucifers. In: K.C. Spencer (Ed.), Chemical Mediation of Coevolution. Academic Press, San Diego, California, pp. 303-316.

Romanucci-Ross, L. and Moerman, D.E. (1988) The extraneous factor in western medicine, Ethos $16,146-166$.

Rosenthal, G.A. and Janzen, D.H. (1979) Herbivores: Their Interaction with Secondary Plant Metabolites. Academic Press, Orlando, Florida, 718 pp.

Saxena, R.C., Nath, R., Palit, G., Nigam, S.K. and Bhargava, K.P. (1982) Effect of calophyllolide, a nonsteroidal anti-inflammatory agent, on capillary permeability. Journal of Medicinal Plant Research 44, 246-248.

Seigler, D.S. (1981) Terpenes and plant phylogeny. In: D.A. Young and D.S. Seigler (Eds.), Phytochemistry and Angiosperm Phylogeny. Praeger, New York, pp. 117-148. 
Sendra, J. and Janeczko, Z. (1973) Beta-sitosterol and oleanolic acid in leaves of Symphoricarpos racemosus Hooker. Polish Journal of Pharmacology and Pharmacy 25, 607-610.

Shetler, S. and Skog, L.E. (1978) A Provisional Checklist of Species for Flora North America Monographs in Systematic Botany, Vol 1. Missouri Botanical Gardens, St. Louis, 192 pp.

Snedecor, G.W. and Cochran, W.G. (1967) Statistical Methods. 6th Edn. Iowa State University Press, Ames, lowa, pp. 135-171.

Speck, F.G (1917) Medicine practices of the northeastern Algonquians. Proceedings of the 19th International Congress of Americanists - 1915. Washington. D.C., pp. 303-321.

Spencer, K.C. (Ed.) (1988) Chemical Mediation of Coevolution. Academic Press, San Diego, California, $718 \mathrm{pp}$.

Steering Committee of the Physicians' Health Study Group (1988) Preliminary report: findings from the aspirin component of the ongoing physicians' health study. New England Journal of Medicine 318(4), 262-264.

Sullivan, M. and King, L.S. (1947) Effects of resin of podophyllum on normal skin, condylomata acuminata and verrucae vulgares. Archives of Dermatology and Syphilology. 56, 30-47.

Swain, T. (1979) Tannins and lignins. In: G.A. Rosenthal and D.H. Janzen (Eds.), Herbivores: Their interaction with Secondary Plant Metabolites. Academic Press, New York, pp. 657682.

Swanton, J. (1928) Religious Beliefs and Medical Practices of Creek Indians. Bureau of American Ethnology Annual Report No. 42, Smithsonian Institution, Washington, D.C., pp. 473-672.

Thorne, R.F. (1982) Phytochemistry and angiosperm phylogeny: a summary statement. In: D.A. Young and D.S. Seigler (Eds.), Phytochemistry and Angiosperm Phylogeny. Praeger, New York, pp. 233-295.

Turner, N.C. and Bell, M.A.M. (1973) Ethnobotany of Southern Kwakiutl Indians of British Columbia. Economic Botany 27, 257-310.

Uphoff, J.C.Th. (1968) Dictionary of Economic Plants. 2nd Edn. J. Cramer, Wurzburg, Germany, p. 467.

Velisek, J., Kubelka, V., Pudil, F., Svobodova, Z. and Davidek, J. (1981) Volatile constituents of elder (Sambucus nigra, L.): 1. Flowers and leaves. Lebensmittel Wissenschaft und Technologie 14, 309-312. 